\title{
ANALISIS HADIS RIWAYAT BUKHORI NOMOR 4700 SYARAT CALON ISTERI
}

\author{
Oleh \\ Dame Siregar \\ Dosen Fakultas Syariah dan Ilmu Hukum IAIN Padangsidimpuan \\ email : damesiregar@iain-padangsidimpuan.ac.id
}

\begin{abstract}
Abstrac
Marriage requirements must be fulfilled before holding the qobul marriage contract. The law of dowry is fardu and the sunnah. Mahar is given by the husband to the wife after the first wati, if the same is the acknowledgment before the marriage contract that he is an officer. If it is not official then it must be divorced, because unlawful marriage one of them has committed adultery willingly. Mahar agreed before and after the marriage contract. Mahar must be paid by the husband half if divorced before the first wati, but may be forgiven by his ex-wife or guardian, if before the marriage ceremony the dowry has been determined together and and there is no iddah, if there is regret the ex-husband wants to marry her from the beginning of the marriage, dowry, consent qobul. If the dowry has not been determined yet, but the husband is the wife of the wife before the inheritance, then the husband gives gifts to the wife according to the ability of the ex-husband, and there is no doubt, if there is regret the ex-husband wants to marry her from the beginning of the dowry, qobul. Terms of Islamic wives or husbands, balig, if you haven't delayed the wati according to balig. If you still want a woman to be a silence, if the widow has to say yes or want and other terms. The permission of the prospective wife's guardian must be well known, not to be engineered and other fraudulent methods, whether for officers or widows. Prospective husbands or wives should be knowledgeable, gifted, good descendants, and have religion (know mmebca Al-Qur'an, hadith, Mengethui aratinya, fardu 'ain and kifayah, peraktek worship, know which ones are haram and halal, not just like Muslim in identity card. converts must first study the teachings of Islam well. If the adherent is obliged to wait for the marriage one year from the beginning of adultery, then the adulterer and adulterer may be married after a year is awaited. If there is a child resulting from a woman's adultery, then becoming a child is not father's child, guardian of marriage later when married the child is a marriage guardian.Prospective of husband or wife do not be adulterer, LGBT, drinkers of khomar, smokers, thieves, murderers, fraudsters.Do not gather or polygamy between two sisters, with sisters or siblings or a thousand, or with a bundle of wives, either in the same age or as a whole or as a whole, ethics from either a mother or a mother or a mother. although not yet born by biological children. Do not the woman in which her biological mother has been entrusted, if not married, may be allowed to marry. Do not wife other people either Muslim or non-Muslim who are still legitimate. Do not the woman in the other boy's proposal, as well as the woman still iddah whether he is dead, crai or the woman who is married to her husband. Don't muharromah women based on the Koran and Hadith.
\end{abstract}

Kata Kunci; Analisis, Hadis, Syarat, Calon, dan Isteri 


\section{A. Pendahuluan}

Syarat merupakan pendahuluan yang wajib dipenuh sebelum melakukan rukun suatu ibadah. Apabila syarat belum terpenuhi maka hati hati untuk tidak melangsungkan nikah tersebut. Sebahagian pemahaman untuk apa melakukan syarat ujung-ujungnya adalah rukunnya yang menjadi tujuan suatu ibadah. Jawabanna pahala dan manfaat syarat sama dangan pahala rukunnya. Dengan kata lain tidak syah rukun ibadah apabila syaratnya belum terpenuhi. Syarat calon isteri dipenuhi dengan sungguh-sungguh agar jangan mudah bosan, melihatnya, bukan mudah membandingkannya dengan wanita lain, mudah memarahinya, mengejeknya, meninggalkannya, akhirnya mudah untuk menceraikannya, maka anak-anak terlantar hidup dan agamanya. Adapun hadis riwayat al-Bukhari nomor 4700 tersebut adalah sebagai berikut:

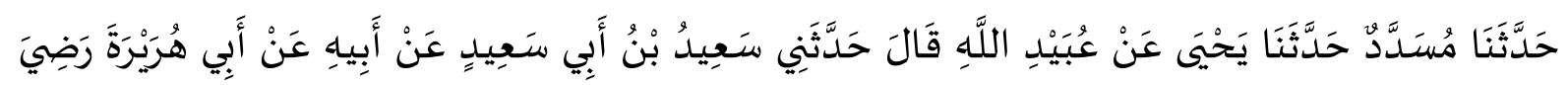

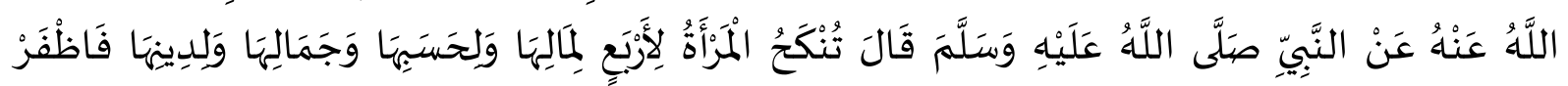

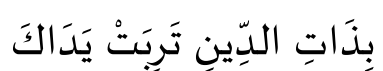

Artinya : Telah menceritakan kepada kami Musaddad telah menceritakan kepada kami Yahya dari Ubaidullah ia berkata; Telah menceritakan kepadaku Sa'id bin Abu Sa'id dari bapaknya dari Abu Hurairah radliallahu 'anhu, dari Nabi Muhammad SAW wasallam, beliau bersabda: "Wanita itu dinikahi karena empat hal, karena hartanya, karena keturunannya, karena kecantikannya dan karena agamanya, aka pilihlah karena agamanya, niscaya kamu akan beruntung." $\{$ Bukhari -4700$\}$.

\section{B. Analisis Hadis Riwayat Bukhari Nomor 4700; Syarat Calon Isteri}

Nikah artinya wathi' atau senggama atau bersetubuh antara suami dan isteri. Ibadah ini merupakan kebutuhan atas kenormalan dua insan yang berbeda, untuk membolehkannya wajib dilalui aturan pernikahan yaitu syarat dan rukunnya. Namun dalam tulisan ini yang dibahas hanya syarat nikah Islam, balig (belum boleh senggama apabila belum balig ditunda dulu senggama seperti pernikahan nabi dengan 'Aisyah), ada izin wali melalui peminangan atau khitbah, janda habis iddah, jangan wanita yang sedang dikhitbah laki-laki lain, mahar yang disepakati namun diberikan setelah senggama awalnya. Syarat calon suami dan isteri karena harta :

1. Wanita jangan nikah syigor dalilnya sebagai berikut:

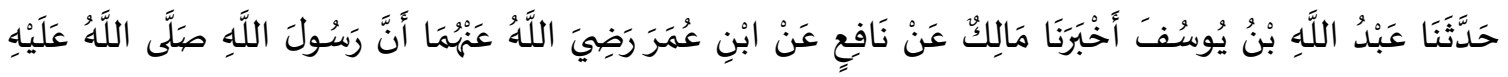

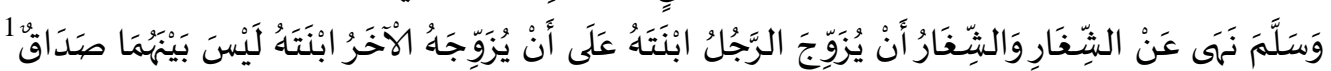

Artinya : Telah menceritakan kepada kami Abdullah bin Yusuf Telah mengabarkan kepada kami Malik dari Nafi' dari Ibnu Umar radliallahu 'anhuma, bahwasanya; 
Rasulullah shallallahu 'alaihi wasallam melarang asy-Syiqhar. Asy-Syighar adalah sesorang menikahkan anak perempuannya kepada orang lain agar orang lain tersebut juga mau menikahkan anak perempuannya dengannya, sedangkan diantara keduanya tidak ada mahar. $\{$ Bukhari -4720$\}$

Penguat:

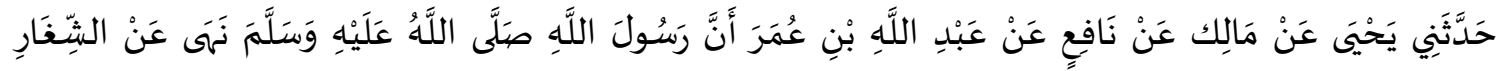

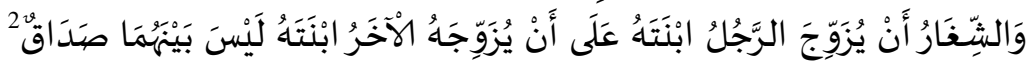

Artinya : Telah menceritakan kepadaku Yahya dari Malik dari Nafi' dari Abdullah bin Umar berkata, "Rasulullah SAW melarang tentang nikah syighar. Syighar adalah seseorang yang menikahkan puterinya dengan orang lain dengan syarat orang tersebut menikahkan puterinya dengan dirinya tanpa mahar antara keduanya." \{Malik - 980\}

Analisis:

a. Apabila ada maharnya bersama-sama boleh saja

b. Namun apabila tidak ada maharnya haram nikah syigor

c. Mahar itu merupakan modal bagi isteri dan modal bagi suami apabila isteri memberikannya dengan ikhlas

2. Jangan janda yang tidak izin darinya secara langsung atau jangan paksaan dari walinya dalilnya sebagai berikut:

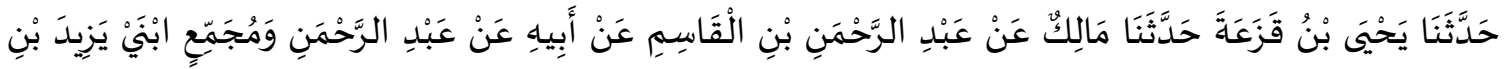

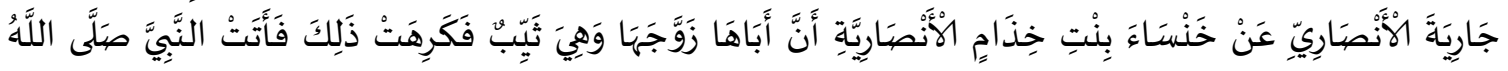

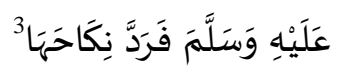

Artinya : Telah menceritakan kepada kami Yahya bin Qaza'ah telah menceritakan kepada kami Malik dari 'Abdurrahman bin al-Qasim dari ayahnya dari 'Abdurrahman dan Mujamma', dua anak Yazid bin Jariyah al-Anshari, dari Khansa' binti Khidzam Al Anshariyah; bahwa ayahnya mengawinkannya ketika itu ia janda dengan lak-laki yang tidak disukainya, kemudian dia menemui nabi Muhammad SAW wasallam dan beliau membatalkan pernikahannya. \{Bukhari - 6432\}

$\underline{\text { Analisis }}$

a. Boleh saja wanita tidak mau sama calon suami pilihan orangtuanya disebabkan harta dan penyebab lain

b. Maka pilihan orangtua atau pilihan calon isteri seharusnya adakan khitbah atau peminangan dengan baik dan bersahaja

c. Kemudian dilanjutkan jenjang mahar dan akad nikah

3. Jangan wanita nikah sirri dalilnya sebagai berikut:

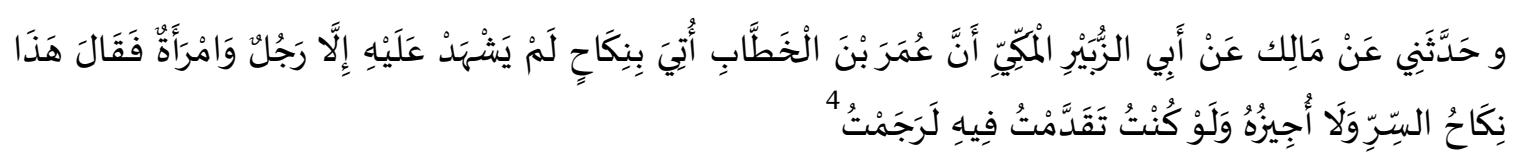

Artinya : Telah menceritakan kepadaku dari Malik dari Abu Az Zubair al-Maki berkata, "Pernah dihadapkan kepada Umar Ibnul Khattab suatu pernikahan yang hanya disaksikan oleh seorang laki-laki dan seorang wanita, maka Umar berkata, "Ini adalah nikah sirri, 
saya tidak membolehkannya. Sekiranya saya menemukannya, niscaya saya akan merajamnya." \{Malik - 982\}

Analisis :

a. Nikah sirri adalah nikah di mana saksinya tidak sempurna syaratnya yaitu dua orang laki-laki, bukan satu laki-laki dan satu wanita

b. Berarti wanita tidak syah menjadi saksi dalam pernikahan hanya boleh saksi jual beli atau utang piutang, yaitu satu pria dan dua wanita \{Qs., al-Baqarah: 282\}

\section{Karena Keturunan:}

1. Jangan wanita masih masa iddah, hukumannya dipukul dan menjadi muharrom Abadan artinya haram selamanya lawan dari muharrom muwaqqot haram sementara contoh mengumpul dua bersaudara atau bersama bunde atau eteknya atau dengan putrid sadara kandung isteri dalilnya sebagai berikut:

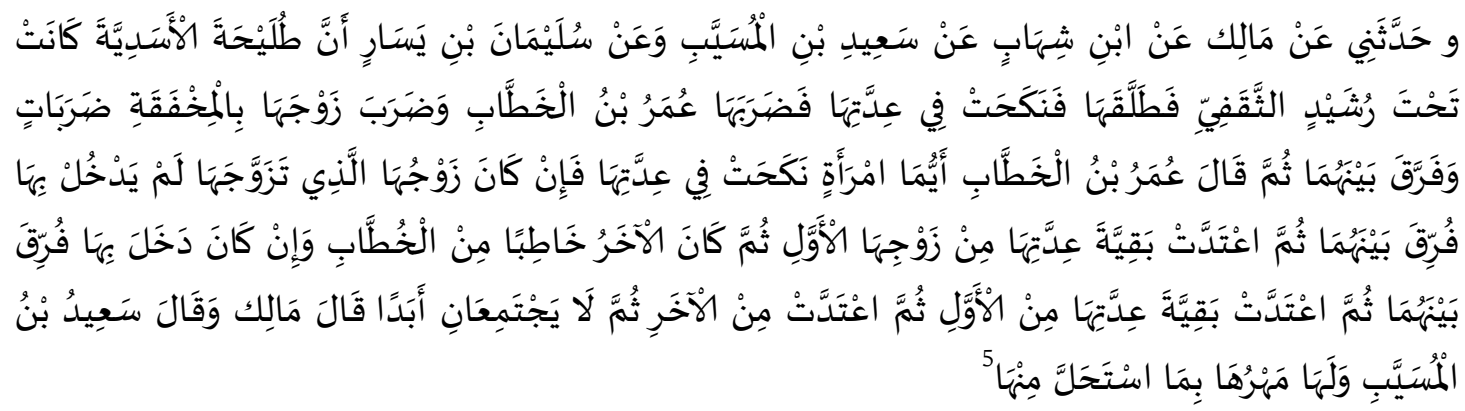
Artinya : Telah menceritakan kepadaku dari Malik dari Ibnu Syihab dari Sa'id Ibnul Musayyab dari Sulaiman bin Yasar berkata, "Thulaihah al-Asadiyah adalah isteri Rusyaid ats-Tsaqafi, tetapi kemudian ia menceraikannya. Thulaihah kemudian menikah pada masa iddahnya. ' Umar Ibnul Khattab lantas memukulnya, demikian juga dengan suaminya, ia memukul Thulaihah dengan cambuk berkali-kali. Umar kemudian memisahkan antara Thulaihah dengan suaminya (yang kedua). Setelah itu ia berkata, "Wanita mana saja yang menikah pada masa iddahnya, apabila suaminya yang menikahinya belum menyetubuhinya maka keduanya harus dipisahkan, lalu ia harus melanjutkan sisa masa iddahnya dari suami yang pertama. Dan suami yang kedua itu setatusnya sebagai pelamar saja. Tetapi apabila ia (suami kedua) telah menggaulinya, maka keduanya dipisahkan, lalu Isterinya melakukan iddah pada sisa masa iddahnya dari suaminya yang pertama kemudian ditambah dengan iddah dari suaminya yang kedua, dan keduanya tidak boleh bersama lagi untuk selamanya." Malik berkata; "Sa'id Ibnul Musayyab berkata; 'Perempuan tersebut berhak mendapatkan mahar (dari suami kedua), karena ia telah mensetubuhinya." \{Malik $983\}$

Analisis:

a. Wanita berhak mendapatkan mahar dari pria yang menyetubuhinya walaupun menikahi dalam masa iddah suami pertama apabila tidak diketahuinya hal itu salah

b. Wanita wafat suamiya maka idaahnya 4 bulan 10 hari. Apabila dia ragu tentang haidnya maka wajib menunggunya sampai tidak ada kekhawatirannya dia hamil. 
c. Iddah merupakan harga diri seorang wanita menjadi indikator keturunan yang terhormat

d. Bukan seperti barang atau hewan secepatnya boleh dijual setelah dikembalikan pembeli pertama dan selanjutnya

4. Jangan menikahi wanita hamba setelah menikahi wanita merdeka untuk dimadu kecuali ada rido dari wanita merdeka tersebu dalilnya sebagai berikut:

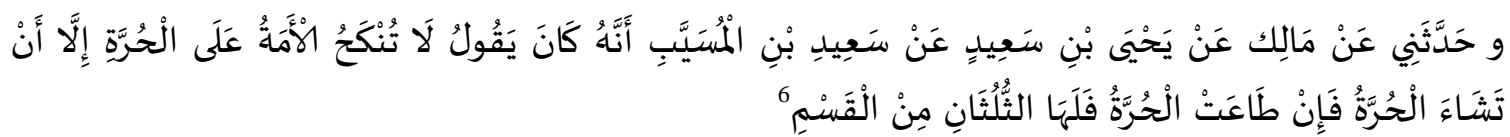
Artinya : Telah menceritakan kepadaku dari Malik dari Yahya bin Sa'id dari Sa'id Ibnul Musayyab ia berkata; "Hamba sahaya tidak boleh dinikahi untuk dimadu dengan wanita merdeka, kecuali apabila wanita merdeka tersebut rida. Apabila wanita merdeka tadi menyetujui maka dia berhak mendapatkan dua pertiga dalam pembagian." \{Malik - 984\} Analisis:

a. Pria merdeka sewajarnya menikah dengan wanita merdeka;

b. Apabila khawatir jatuh zina, maka boleh wanita hamba;

c. Izin dari isteri merdeka merupakan dasar hukumnya ada izin isteri pertama untuk poligami suami;

d. Demikian maksud surah an-Nisa' ayat 25;

e. Wanita bukan sembarang dimadu karena menimbulkan cekcok dalam rumah tangga dengan isteri pertama dan selanjutnya, perlu dihargai keharmonisan rumah tangga.

5. Jangan wanita sahaya dibeli pria, pada hal mantan isteri yang ditolak tiga dalilnya sebagai berikut:

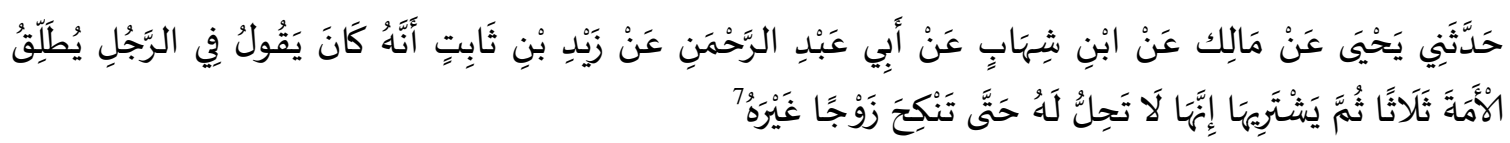

Artinya : Telah menceritakan kepadaku Yahya dari Malik dari Ibnu Syihab dari Abu Abdurrahman dari Zaid bin Tsabit Bahwasanya ia berkata tentang seorang laki-laki yang mentalak budak wanitanya dengan talak tiga, kemudian membelinya kembali, "Budak wanita itu tidak halal baginya sehingga ia menikah dengan laki-laki lain. \{Malik-985\}.

6. Apabila masih talak roja'i masih boleh dalilnya sebagai berikut:

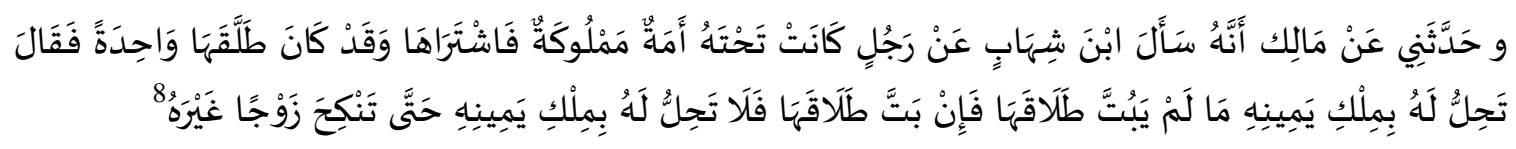
Artinya : Telah menceritakan kepadaku dari Malik bahwasanya ia pernah bertanya kepada Ibnu Syihab tentang laki-laki yang mempunyai isteri seorang budak, lalu ia membelinya setelah ia mentalaknya dengan talak satu. Ibnu Syihab menjawab, "Budak itu tetap halal baginya karena status kepemilikan budak, selama ia tidak menjatuhkan talak ba'in. Tetapi apabila ia telah menjatuhkan talak ba'in, maka tidak halal baginya walau statusnya sebagai budak miliknya, hal itu hingga budak tersebut menikah dengan laki-laki lain." \{Malik - 986\} 
$\underline{\text { Analisis: }}$

Hadis ini merupakan dalil bahwa status talak budak sama dngan talak wanita merdekayaitu talak rojai (dua klai talak) dan talak wajib hamba menikah dengan lakilaki lain dan disetubuhuinya syarat boleh kembali kepada suami pertama setelah habis masa iddahnya, dan jangan melalui muhalli dan muhallal 'alaih

7. Larangan wanita hamba dipoligami dengan putri hamba itu dalilnya:

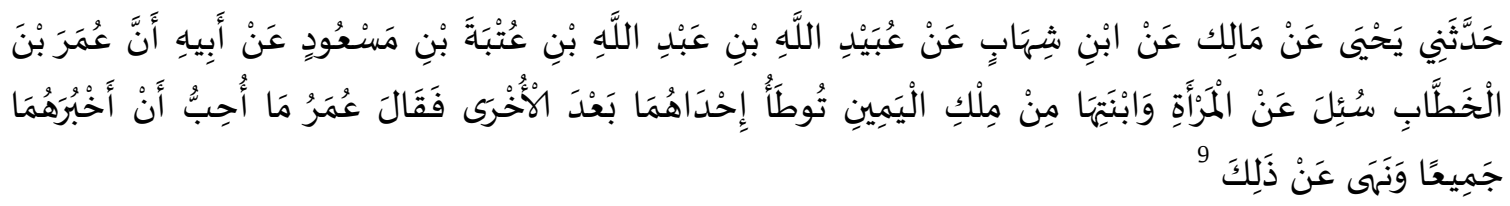

Artinya : Telah menceritakan kepadaku Yahya dari Malik dari Ibnu Syihab dari 'Ubaidullah bin Abdullah bin 'Utbah bin Mas'ud dari Bapaknya bahwasanya Umar bin Khattab ditanya tentang seorang budak wanita dan puterinya, yang telah disetubuhi salah satunya setelah yang lainnya juga. Umar berkata; "Saya tidak suka apabila menggauli keduanya." 'Umar Ibnul Khattab melarang perbuatan tersebut. \{Malik - 987\} Analisis:

a. Jangan dianggap apabila janda yang hamba boleh saja dibeli bersama putri kandungnya dari laki-laki pertama sekalipun suaminya juga seorang hamba

b. Persoalan nikah antara merdeka dengan hamba tidak didiskriminasikan dalam Islam

c. Maka Islam menghargai hamba sampai mendapatkan status merdeka

8. Haram menikahi poligami dua bresaudari dalam satu kepemilikan sama-sama hamba, dalilnya sebagai berikut:

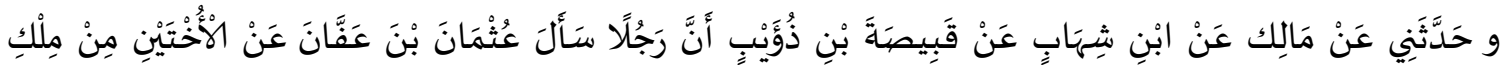

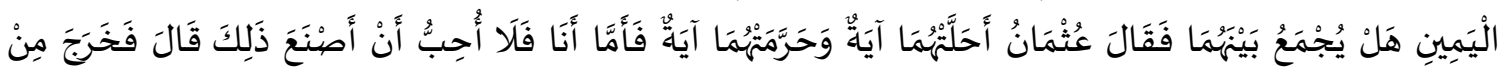

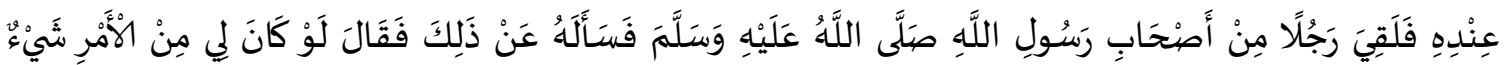

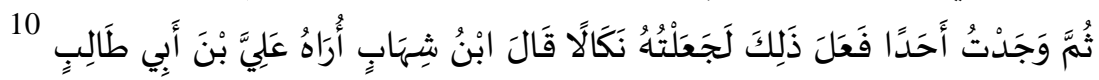
Artinya : Telah menceritakan kepadaku dari Malik dari Ibnu Syihab dari Qabishah bin Dzu aib bahwa ada seorang laki-laki bertanya kepada Utsman bin Affan tentang dua perempuan yang bersaudara berada di bawah kepemilikan seseorang, apakah keduanya boleh digauli? Utsman menjawab; "Ayat al-Qur'an telah menghalalkan keduanya, namun ada juga ayat lain mengharamkan keduanya (untuk digauli). Tetapi aku sendiri tidak suka untuk melakukan hal itu (menggauli dua-duanya)." Qabishah berkata; "Lakilaki tersebut kemudian keluar meninggalkan kediaman Utsman dan berjumpa dengan seorang sahabat Nabi Muhammad SAW wasallam, lalu ia tanyakan hal itu kepadanya. Sahabat itu lalu menjawab, "Sekiranya aku mempunyai wewenang dalam hal itu, lalu aku mendapati orang yang melakukannya niscaya aku akan memberinya hukuman." Ibnu Syihab berkata; "Menurutku sahabat tersebut adalah Ali bin Abu Thalib." \{Malik - 988\} Analisis:

a. Mempoligami hamba atau merdeka dua yang bersaudara atau antara Ibu dan putri seorang janda haram hukumnya 
b. Apabila terjadi dan sudah disetubuhi salah satunya wajib salah satu diceraikan atau duanya diceraikan

c. Apabila jandanya dinikahi belum disetubuhi, boleh menikahi putrinya

d. Namun apabila putri janda itu dinikahi diceraikan walaupun belum disetubuhi maka haram menikahi Ibu kandungnya atau janda itu

e. Demikian menikahi isteri anak kandung, apabila diceraikannya walupun belum disetubuhinya haram dinikahi ayah kandung suaminya atau mertua

f. Ayat yang membolehkan surah al-Maidah ayat 5

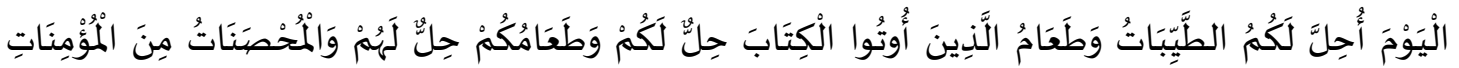

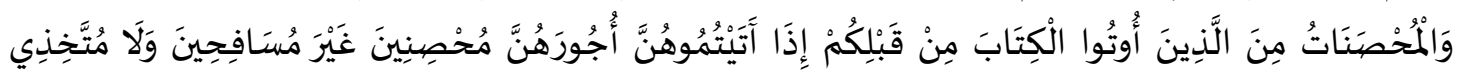

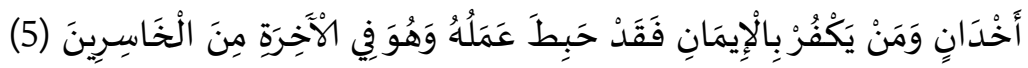
Artinya : Pada hari ini dihalalkan bagimu yang baik-baik. Makanan (sembelihan) orang-orang yang diberi Al Kitab itu halal bagimu, dan makanan kamu halal (pula) bagi mereka. (Dan dihalalkan mangawini) wanita yang menjaga kehormatan diantara wanita-wanita yang beriman dan wanita-wanita yang menjaga kehormatan di antara orang-orang yang diberi Al Kitab sebelum kamu, bila kamu telah membayar mas kawin mereka dengan maksud menikahinya, tidak dengan maksud berzina dan tidak (pula) menjadikannya gundik-gundik. Barangsiapa yang kafir sesudah beriman (tidak menerima hukum-hukum Islam) maka hapuslah amalannya dan ia di hari kiamat termasuk orang-orang merugi. Ada yang mengatakan wanita-wanita yang merdeka". ${ }^{11}$

\section{Analisis:}

1. Ayat ini harus dipahami boleh menikahi ahli kitab sebelum habis al-Qur'an diturunkan, apabila sudah selesai haram menikahi ahli kitab seperti menikahi non Muslim \{Qs. al-Baqarah/2:221\}

2. Hamba dalam ayat di atas tidak dibatasi secara jelas berapa jumlah hamba yang boleh dinikahi

g. Ayat yang mengharamkan menikahi isteri ayah kandung yang diceraikan sudah diwatinya, apabila belum boleh dinikahi anak kandung suami adalah surah an-Nisa' ayat 23

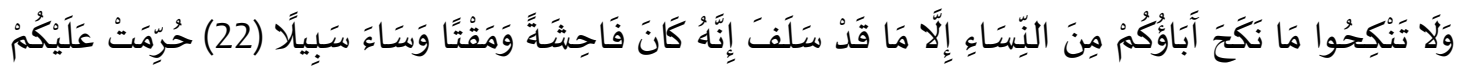

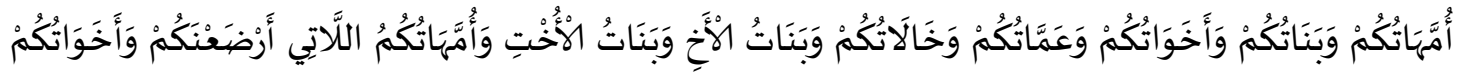

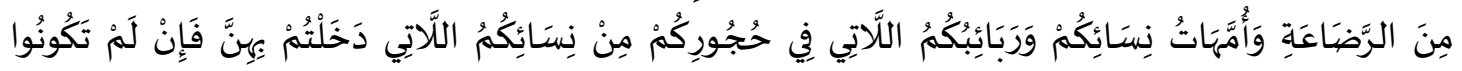




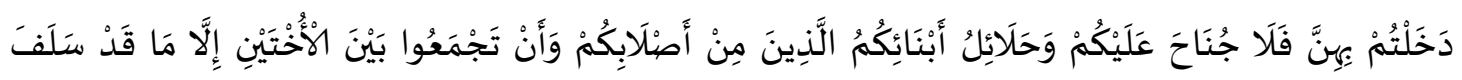

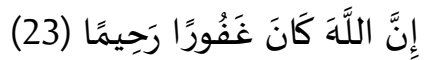

Artinya: Diharamkan atas kamu (mengawini) ibu-ibumu; anak-anakmu yang perempuan $^{[281]}$; saudara-saudaramu yang perempuan, saudara-saudara bapakmu yang perempuan; saudara-saudara ibumu yang perempuan; anak-anak perempuan dari saudara-saudaramu yang laki-laki; anak-anak perempuan dari saudara-saudaramu yang perempuan; ibu-ibumu yang menyusui kamu; saudara perempuan sepersusuan; ibu-ibu isterimu (mertua); anak-anak isterimu yang dalam pemeliharaanmu dari isteri yang telah kamu campuri, tetapi apabila kamu belum campur dengan isterimu itu (dan sudah kamu ceraikan), maka tidak berdosa kamu mengawininya; (dan diharamkan bagimu) isteri-isteri anak kandungmu (menantu); dan menghimpunkan (dalam perkawinan) dua perempuan yang bersaudara, kecuali yang telah terjadi pada masa lampau; sesungguhnya Allah Maha Pengampun lagi Maha Penyayang. Maksud ibu di sini ialah ibu, nenek dan seterusnya ke atas. Dan yang dimaksud dengan anak perempuan ialah anak perempuan, cucu perempuan dan seterusnya ke bawah, demikian juga yang lain-lainnya. Sedang yang dimaksud dengan anak-anak isterimu yang dalam pemeliharaanmu, menurut jumhur ulama termasuk juga anak tiri yang tidak dalam pemeliharaannya". ${ }^{12}$

Analisis:

a. Dua hamba sahaya dibawah kepemilikan satu tuan, haram mempoligaminya

b. Solusinya wajib satu diceraikannya mana di antara keduanya

c. Kemudian boleh dinikahkannya kepada hamba sahaya yang laki-laki, atau kepada laki-laki lain yang merdeka

9. Ada izin wali melalui peminangan atau khitbah, dalilnya sebagai berikut:

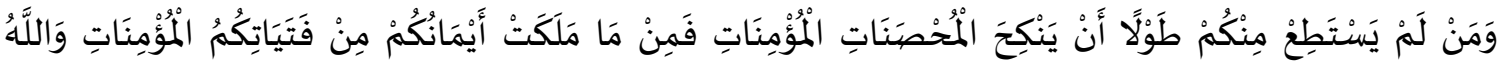

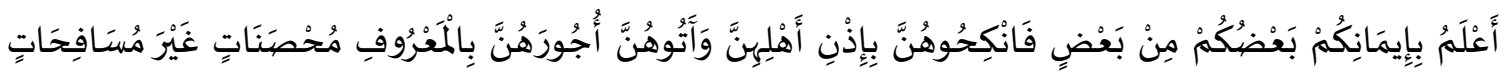

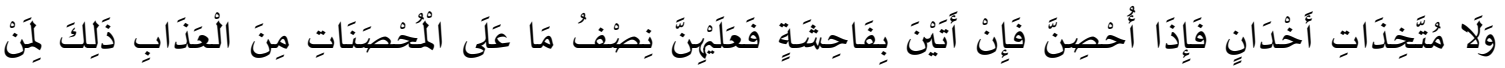

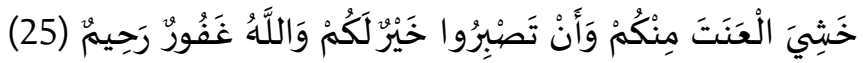

Artinya: Dan barangsiapa diantara kamu (orang merdeka) yang tidak cukup perbelanjaannya untuk mengawini wanita merdeka lagi beriman, ia boleh mengawini wanita yang beriman, dari budak-budak yang kamu miliki. Allah mengetahui keimananmu; sebahagian kamu adalah dari sebahagian yang lain, karena itu kawinilah mereka dengan seizin tuan mereka, dan berilah maskawin mereka menurut yang patut, sedang merekapun wanita-wanita yang memelihara diri, bukan pezina dan bukan (pula) wanita yang mengambil laki-laki lain sebagai piaraannya; dan apabila mereka telah menjaga diri dengan kawin, kemudian mereka melakukan perbuatan yang keji (zina), maka atas mereka separo hukuman dari hukuman wanita-wanita merdeka yang bersuami. (Kebolehan mengawini budak) itu, adalah bagi orang-orang yang takut kepada kemasyakatan menjaga diri (dari perbuatan zina) di antara kamu, dan kesabaran itu lebih baik bagimu. Dan Allah Maha Pengampun lagi Maha Penyayang. Maksudnya: orang merdeka dan budak yang dikawininya itu adalah sama-sama keturunan Adam dan Hawa dan sama-sama beriman". ${ }^{13}$

10. Janda wajib dengan izin walinya dalilnya surah al- Baqarah ayat 232 sebagai berikut: 


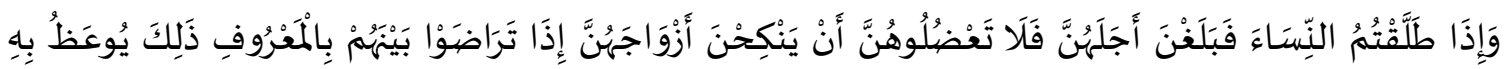

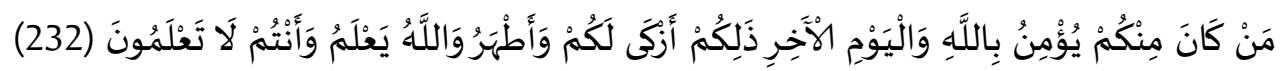

Artinya: Apabila kamu mentalak isteri-isterimu, lalu habis masa iddahnya, maka janganlah kamu (para wali) menghalangi mereka kawin lagi dengan bakal suaminya, apabila telah terdapat kerelaan di antara mereka dengan cara yang ma'ruf. Itulah yang dinasehatkan kepada orang-orang yang beriman di antara kamu kepada Allah dan hari kemudian. Itu lebih baik bagimu dan lebih suci. Allah mengetahui, sedang kamu tidak mengetahui. Kawin lagi dengan bekas suami atau dengan laki-laki yang lain". ${ }^{14}$

Analisis:

a. Izin wali merupakan penghargaan kepada wanita tersebut dan walinya

b. Islam bukan meremehkan wanita sembarang menikah semaunya

c. Karena wanita mudah digoda laki-laki, kemudian mudah pria meninggalkan wanita dengan salah yang sedikit saja

d. Apabila ada izin wali maka sulit rasa suami menceraikan isterinya

e. Karena menikah berikutnya akan berhadapan dengan wali isteri selanjutnya

11. Ayat di atas dijelaksan hadis berikut:

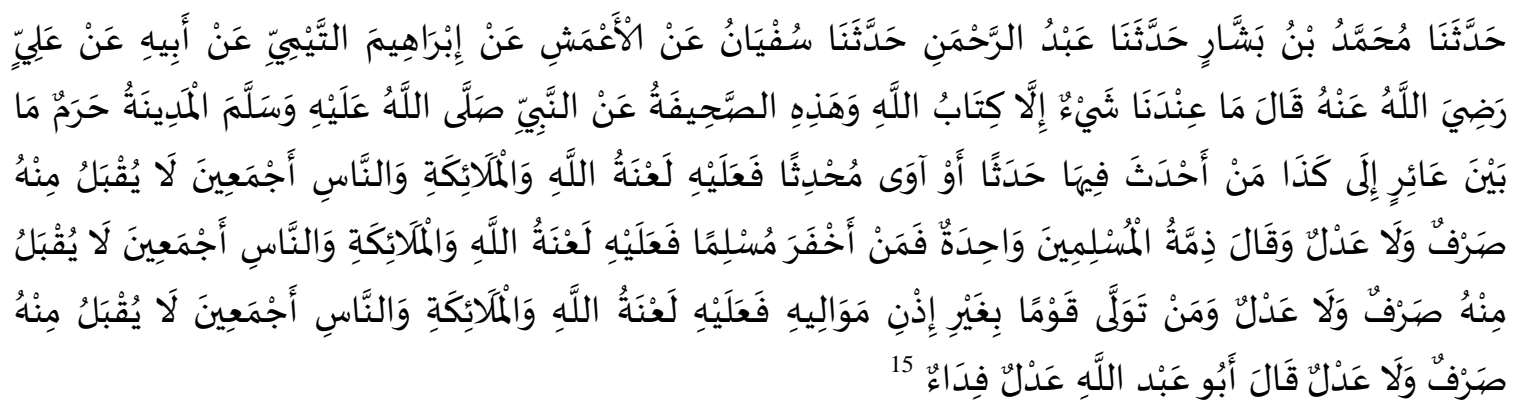

Artinya : Telah menceritakan kepada kami Muhammad bin Basysyar telah menceritakan kepada kami 'Abdurrahman telah menceritakan kepada kami Sufyan dari al-A'masy dari Ibrahim at-Taymiy dari bapaknya dari 'Ali radliallahu 'anhu berkata: "Tidak ada sesuatu yang kami miliki kecuali kitabullah dan ash-Shahifah (lembaranlembaran hadits) ini, dari Nabi Muhammad SAW wasallam bersabda: "Madinah adalah tanah suci yang wilayahnya antara gurun sahara hingga ini. Maka barangsiapa yang berbuat kemungkaran (bid'ah) yang dilarang agama didalamnya atau membantu orang berbuat bid'ah maka orang itu akan mendapat laknat dari Allah, para malaikat dan seluruh manusia dan tidak akan diterima darinya amalan 'ibadah wajib dan sunnahnya" (atau taubat dan tebusannya). Dan Beliau bersabda: "Perlindungan Kaum Muslimin adalah satu, maka barangsiapa melepas ikatan perjanjian dengan seorang muslim maka orang itu akan mendapat laknat dari Allah, para malaikat dan seluruh manusia dan tidak akan diterima darinya amalan 'ibadah wajib dan sunnahnya baginya dan barangsiapa yang mengambil perwalian suatu kaum tanpa seizin walinya maka orang itu akan mendapat laknat dari Allah, para malaikat dan seluruh manusia dan tidak akan diterima darinya amalan 'ibadah wajib dan sunnahnya". Berkata, Abu 'Abdullah Bukhari: istilah al'adh artinya: "Tebusan". \{Bukhari-1737\}

Analisis:

a. Izin dari wali wajib syarat nikah baik janda maupun perawan 

b. Perawan diamnya menunjukkan maunya
c. Apabila janda wajib ada kata ya.

12. Calon isteri jangan masih dalam pinangan laki-laki lain dalilnya sebagai berikut:

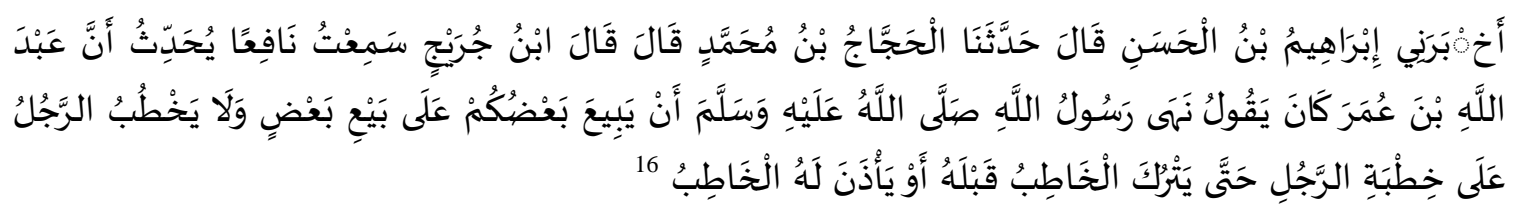

Artinya: Telah mengkhabarkan kepada kami Ibrahim bin Al Hasan, ia berkata; telah menceritakan kepada kami Al Hajjaj bin Muhammad, ia berkata; berkata Ibnu Juraij; saya pernah mendengar Nafi' menceritakan bahwa Abdullah bin Umar pernah berkata; Rasulullah shallallahu 'alaihi wasallam melarang sebagian kalian menjual di atas jual beli sebagian yang lain, dan janganlah seseorang meminang di atas pinangan orang lain hingga orang yang meminang sebelumnya meninggalkan pinangannya atau mengizinkan memberikan izin. \{Nasai - 3191\}

13. Jangan wanita yang dimuhallal namun belum disetubuhi suami kedau setelah talak 3 dari suami pertama, dalilnya sebagai berikut:

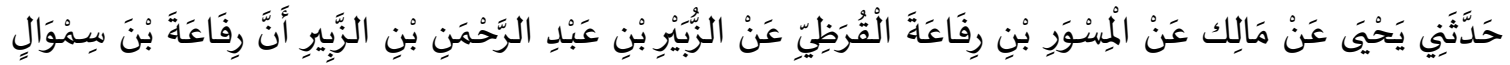

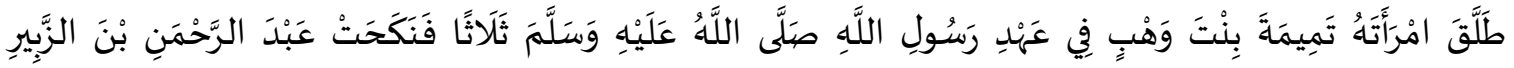

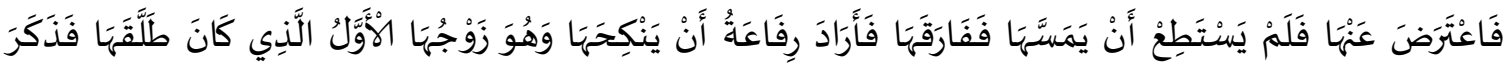

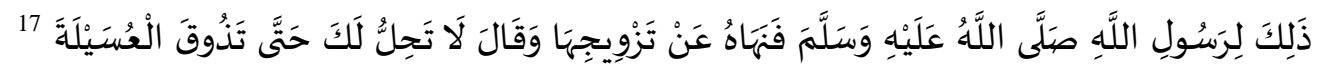
Artinya: Telah menceritakan kepadaku Yahya dari Malik dari Al Miswar bin Rifa'ah Al Quradli dari Zubair bin Abdurrahman bin Zubair berkata, "Pada masa Rasulullah shallallahu 'alaihi wasallam Rifa'ah bin Simwal mentalak isterinya yang bernama Tamimah binti Wahab sebanyak tiga kali. Kemudian bekas isterinya menikah dengan Abdurrahman bin Zubair. Namun Abdurrahman mempunyai masalah karena tidak mampu menyetubuhinya, sehingga ia kembali mencerikan Tamimah. Maka Rifa'ah ingin menikahinya kembali, karena dia adalah suami pertama yang pernah menceraikannya. Lalu hal itu disampaikan kepada Rasulullah shallallahu 'alaihi wasallam, namun beliau melarangnya seraya bersabda: "Tidak halal bagimu untuk menikahinya lagi, hingga ia merasakan nikmatnya madu laki-laki yang lain (bersetubuh) ." \{Malik - 975\}

Penguat:

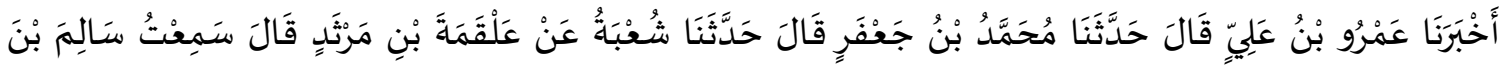

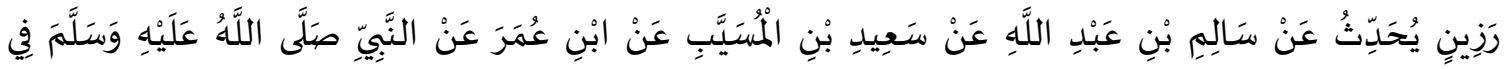

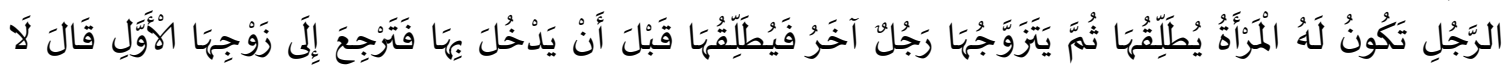

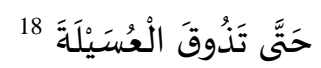

Artinya: Telah mengabarkan kepada kami 'Amr bin Ali, ia berkata; telah menceritakan kepada kami Muhammad bin Ja'far, ia berkata; telah menceritakan kepada kami Syu'bah dari 'Alqamah bin Martsad, ia berkata; saya mendengar Salim bin Razin menceritakan dari Salim bin Abdullah dari Sa'id bin al-Musayyab dari Ibnu Umar dari Nabi Muhammad SAW wasallam mengenai seseorang yang memiliki isteri yang ia ceraikan kemudian wanita tersebut dinikahi laki-laki yang lain, lalu ia mencerainya sebelum 
menggaulinya dan ia kembali ke suaminya yang pertama. Beliau bersabda: "Tidak boleh, sampai ia merasakan kenikmatan." \{Nasai - 3361\}

14. Jangan dimadu dengan bunde (saudari kandung ayah atau Ibunya) dalinya sebagai berikut:

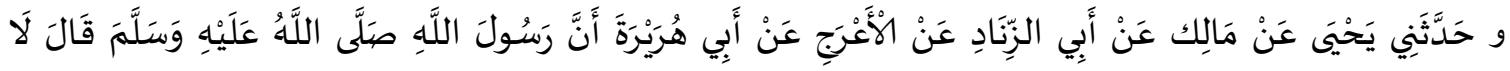

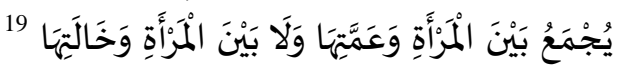
Artinya: Telah menceritakan kepadaku Yahya dari Malik dari Abu Az Zinad dari Al A'raj dari Abu Hurairah bahwa Rasulullah shallallahu 'alaihi wasallam bersabda: "Tidak boleh menikahi seorang perempuan bersamaan dengan bibinya dari pihak bapak dan tidak boleh menikahi perempuan bersamaan dengan bibinya dari pihak ibunya." Penguat Muslim nomor 2514, Abu Dawud nomor 1769, an-Nasai, nomor 3236, Ibn Majah nomor 1920. $\{$ Malik - 977\}

15. Jangan hamba sahaya yang ada janin dari suami sebelumnya, dalilnya sebagai berikut:

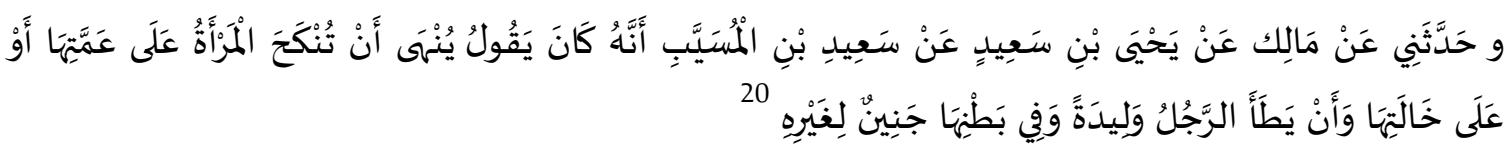

Artinya: Telah menceritakan kepadaku dari Malik dari Yahya bin Sa'id dari Sa'id bin Musayyab berkata; "Tidak boleh menyatukan wanita dengan bibinya dari pihak bapaknya atau dari pihak ibunya. Tidak boleh juga seseorang menyetubuhi isterinya yang sedang mengandung janin orang lain." \{Malik - 978\}

Analisis:

a. Hadis dalil mejelaskan maksud surah at-Thalaq ayat 4, wanita hamil iddahnya sampai melahirkan ditambah masa nifas selesai

b. Maksud janin orang lain adalah janin dari suami sebelumnya yang syah

c. Demikian juga janin hasil zina mereka berdua sebelumnya

d. Karena nak yang syah anak ayah dan Ibu wajib terpenuhi syarat dan rukun nikah

e. Wanita pezina atau wanita yang syah pernikahan, wajib memberitahukan kepada orang banyak atau walinya bahwa dia sedang hamil dalinya surah al-Baqarah ayat 228 sebagai berikut:

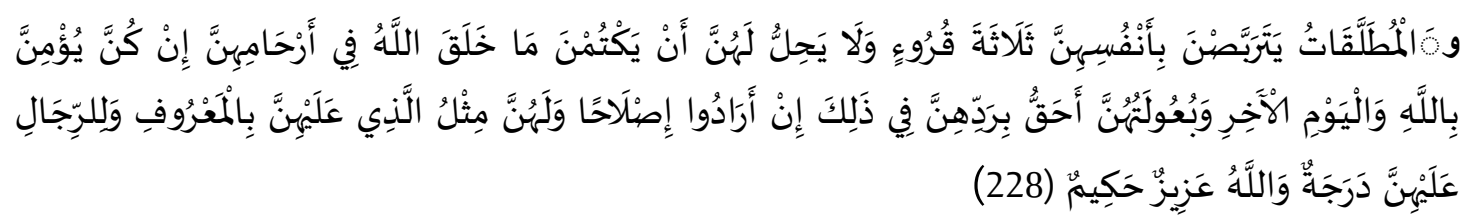

Artinya: wanita-wanita yang ditalak handaklah menahan diri (menunggu) tiga kali quru'. tidak boleh mereka menyembunyikan apa yang diciptakan Allah dalam rahimnya, apabila mereka beriman kepada Allah dan hari akhirat. dan suamisuaminya berhak merujukinya dalam masa menanti itu, apabila mereka (para suami) menghendaki ishlah. dan Para wanita mempunyai hak yang seimbang dengan kewajibannya menurut cara yang ma'ruf. akan tetapi para suami, mempunyai satu tingkatan kelebihan daripada isterinya. dan Allah Maha Perkasa lagi Maha Bijaksana. Quru' dapat diartikan suci atau haidh. Hal ini disebabkan karena suami bertanggung 
jawab terhadap keselamatan dan kesejahteraan rumah tangga (Lihat surat an-Nisaa' ayat 34$)^{21}$

f. Jadi tidak ada isyarat bolehnya wanita hamil hasil zina boleh dinikahkan dengan mantan pria pezinanya atau pria lainnya

g. Maka solusinya, tunggu satu tahun dan atau sampai melahirkan

16. Jangan Ibu isterinya dalilnya sebagai berikut:

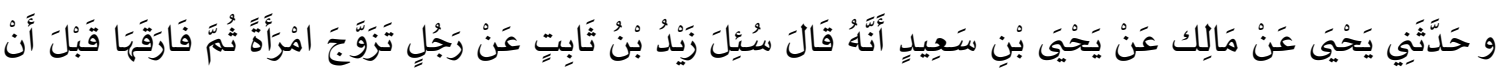

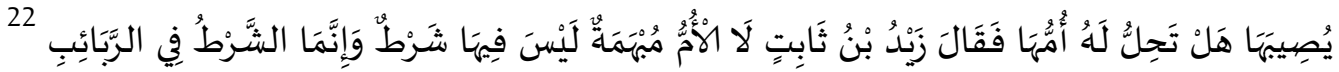

Artinya: Telah menceritakan kepadaku Yahya dari Malik dari Yahya bin Sa'id berkata; " Zaid bin Tsabit ditanya tentang seseorang yang menikahi wanita kemudian menceraikannya sebelum menyetubuhinya, apakah ibunya halal untuk dinikahi?" Zaid bin Tsabit menjawab; "Tidak boleh. Karena setatus ibu tidak dirinci, dan tidak ada syarat padanya. Adapun yang disebutkan syaratnya adalah pada anak tiri." \{Malik - 979\}

17. Jangan putri kandung isteri dalilnya surah an-Nisa' ayat 23

18. Sejarah mahar surah al-Qasash ayat 27 menceritakan lafazh untuk menikahkan salah satu

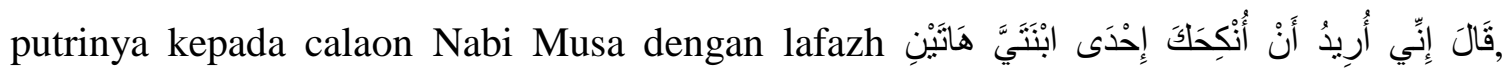
Artinya, Nabi Syu'aib berkata langsung kepada Musa: "Sesungguhnya aku bermaksud menikahkan kamu dengan salah seorang dari kedua putriku ini”. Ayat ini sesuai dengan hadis berikut: Ayat di atas dijelaskan Nabi dalam riwayat Ahmad berikut:

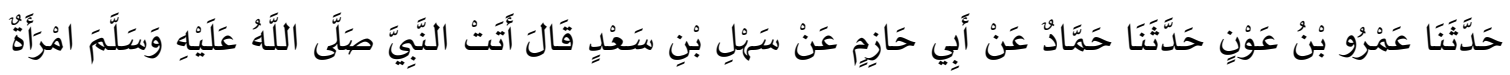

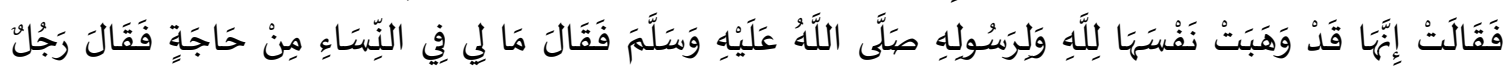

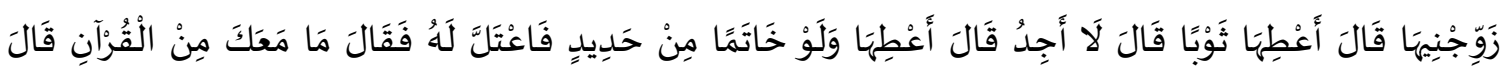

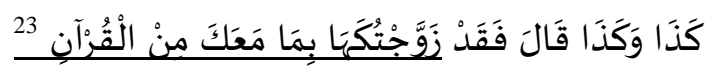

Artinya: Telah menceritakan kepada kami Amru bin 'Aun Telah menceritakan kepada kami Hammad dari Abu Hazim dari Sahl bin Sa'd ia berkata; Seorang wanita mendatangi Nabi Muhammad SAW wasallam dan berkata bahwasanya, ia telah menyerahkan dirinya untuk Allah dan Rasul-Nya shallallahu 'alaihi wasallam. Maka beliau bersabda: "Aku tidak berhasrat terhadap wanita itu." Tiba-tiba seorang laki-laki berkata, "Nikahkanlah aku dengannya." Beliau bersabda: "Berikanlah mahar (berupa) pakaian padanya." Laki-laki itu berkata, "Aku tidak punya." Beliau pun bersabda kembali, "Berikanlah meskipun hanya berupa cincin besi." Ternyata ia pun tak punya. Kemudian beliau bertanya, "Apakah kamu memiliki hafalan al-Qur'an?" laki-laki itu menjawab, "Ya, surat ini dan ini." Maka beliau bersabda: "Aku telah membolehkan menikahkah dengan wanita itu, dengan mahar hafalan al-Qur'anmu." \{Bukhari - 4641\}

Analisis:

a. Seorang wanita, wanita tidak diberi tahu siapa namanya dan siapa nama ayahnya

b. Apabila seorang wanita mau menikah, tentu nabi harus tahu putri siapa karena ayahnya yang wajib menjadi walinya, apabila tidak ada baru muharramnya yang ada seperti saudara kandung, kakek, paman, apabila tidak ada lagi maka wali hakim 
c. Mendatangi nabi Muhammad SAW wasallam dan berkata bahwasanya, ia telah menyerahkan dirinya untuk Allah dan Rasulullah SAW. Maksunya ia mau menikah وَهَبَتْ نَفْنَهَا لِنَّهِ وَرِرَسُولِهِ

d. Hadis ini menjelaskan maksud ayat surah al-Ahzab 33:50 berikut:

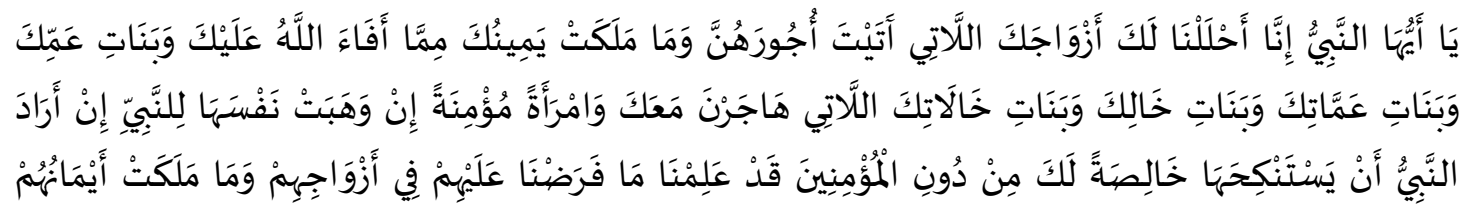

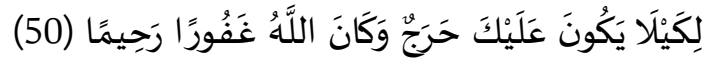

Artinya: Hai Nabi, sesungguhnya Kami telah menghalalkan bagimu isteri- isterimu yang telah kamu berikan mas kawinnya dan hamba sahaya yang kamu miliki yang termasuk apa yang kamu peroleh dalam peperangan yang dikaruniakan Allah untukmu, dan (demikian pula) anak-anak perempuan dari saudara laki-laki bapakmu, anak-anak perempuan dari saudara perempuan bapakmu, anak-anak perempuan dari saudara laki-laki ibumu dan anak-anak perempuan dari saudara perempuan ibumu yang turut hijrah bersama kamu dan perempuan mukmin yang menyerahkan dirinya kepada Nabi kalau Nabi mau mengawininya, sebagai pengkhususan bagimu, bukan untuk semua orang mukmin. Sesungguhnya Kami telah mengetahui apa yang Kami wajibkan kepada mereka tentang isteri-isteri mereka dan hamba sahaya yang mereka miliki supaya tidak menjadi kesempitan bagimu. Dan adalah Allah Maha Pengampun lagi Maha Penyayang. ${ }^{24}$

e. Maka beliau bersabda: Aku tidak berhasrat terhadap wanita itu, maksudnya tidak mau menerima tawaran wanita yang tidak disebut namanya dan nama ayahnya

f. Tiba-tiba seorang laki-laki berkata, "Nikahkanlah aku dengannya" kalimat ini permintaan pria yang ingin menikahinya

g. Belum bisa dijadikan lafahz kalimat perwalian agar Nabi menjadi wali nikah wanita tersebut

h. Karena kalimat perwalian harus dari ayah atau wali lain dari pihak wanita tersebut dalam Islam

i. Beliau bersabda: "Berikanlah mahar (berupa) pakaian padanya. Mennetukan mahar seharusnya wanita tersebut dan walinya bukan Nabi sendiri

j. Hanya dasar hukum pertimbangan hukum minimalnya mahar dalam Islam

k. Berarti sebelum akad nikah sudah boleh ditentukan maharnya, sesuai dengan surah alBaqarah 2:237. Berarti Nabi memberikan penjelasan bolehnya sehelai pakaian mahar wanita, sekarang aplikasinay seperangkat alat shalat

1. Laki-laki itu berkata, "Aku tidak punya." Beliau pun bersabda kembali, Berikanlah meskipun hanya berupa cincin besi." Ini merupakan penjelasan semakin minimnya ukuran mahar sekalipun cincin terbuat dari besi, ternyata laki-laki itupun tidak punya. 
m. Kemudian beliau bertanya, "Apakah kamu memiliki hafalan al-Qur'an?" laki-laki itu menjawab, "Ya, surat ini dan ini."

n. Maka beliau bersabda: "Aku telah membolehkan menikahkah dengan wanita itu, dengan mahar hafalan al-Qur'anmu.

o. Apabila nabi sebagai wali hakim tentu, ijabnya disebutkan wali nasabya atau nama ayahnya serta izinnya, seperti : Aku nikahkan kepada si fulanah putri si fulan dengan mahar dengan mahar hafalan al-Qur'anmu

p. Ada pemikiran, apabila terjadi perbedaan maka sebaiknya kembalikan nas yang khusus bukan dalil umum

q. Dalil umunya فَفَدْ زَوَجْنُكَكَا بِمَا مَعَكَ مِنْ الْقُرْآنِ sedangkan dalil khususnya dalam ijab qabul

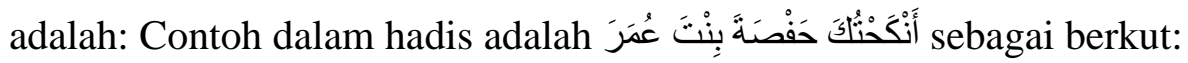

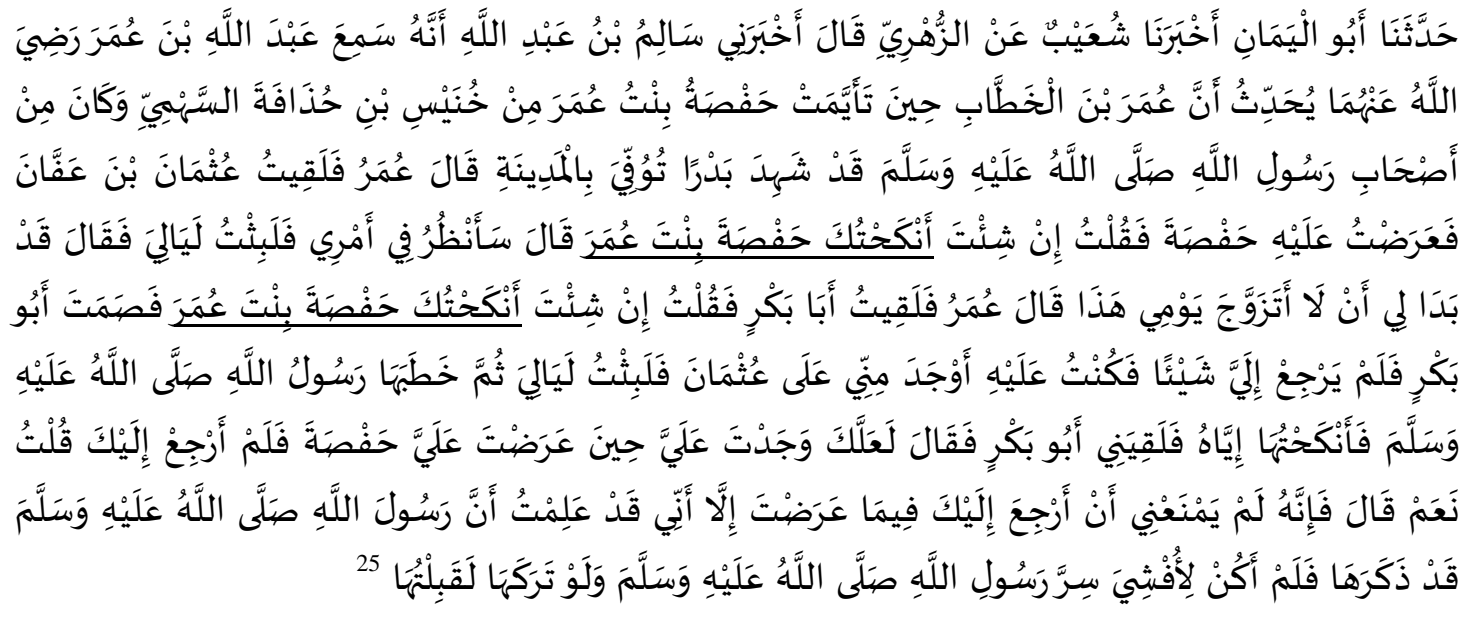

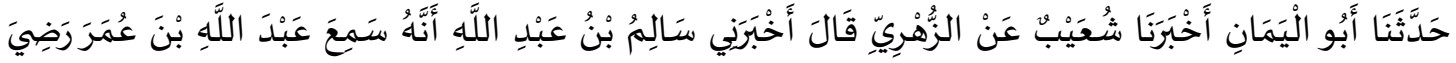

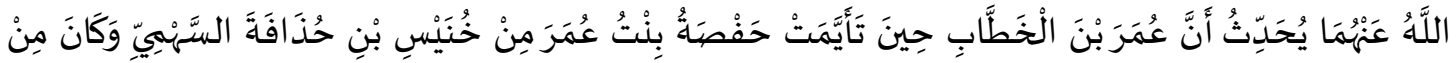

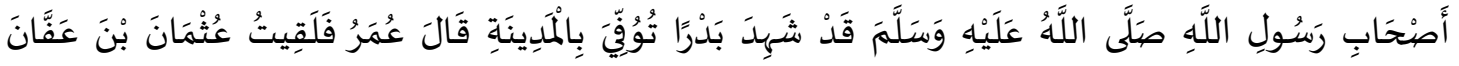

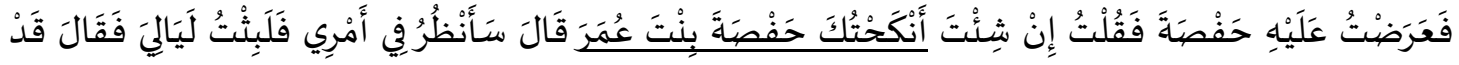

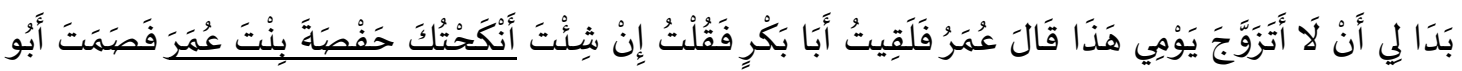

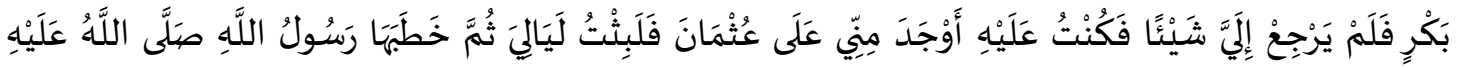

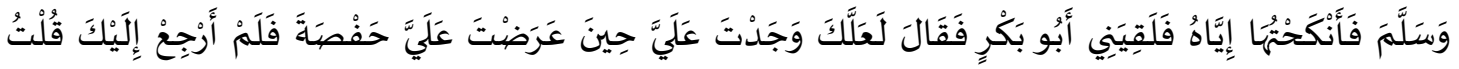

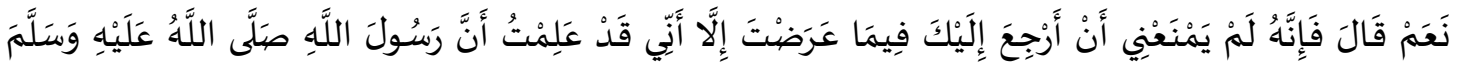

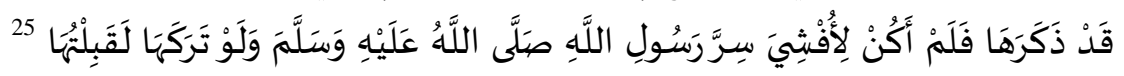

Artinya: Telah menceritakan kepada kami Abu al-Yaman telah mengabarkan kepada kami Syu'aib dari az-Zuhri dia berkata, telah mengabarkan kepadaku Salim bin Abdullah bahwa dia mendengar Abdullah bin Umar radliallahu 'anhuma bercerita, bahwa Umar bin Khattab berkata ketika Hafshah binti Umar menjanda dari Khunais bin Hudzafah as-Sahmi -ia termasuk di antara sahabat Rasulullah shallallahu 'alaihi wasallam yang ikut serta dalam perang Badr dan meninggal di Madinah-, Umar berkata, "Maka aku datangi Usman bin 'Affan dan kutawarkan Hafshah kepadanya. Aku berkata, "Apabila engkau mau, maka aku akan menikahkan kepadamu dengan Hafshah binti Umar." Utsman hanya memberi jawaban, "Aku akan melihat perkaraku dulu, " aku lalu menunggu beberapa malam, kemudian ia menemuiku dan berkata, "Nampaknya aku tidak akan menikah pada saat ini." Umar berkata, "Kemudian aku menemui Abu Bakr, kukatakan padanya, "Apabila engkau menghendaki, maka aku akan menikahkan kepadamu dengan Hafshah binti Umar." Abu Bakar hanya terdiam dan tidak memberi jawaban sedikitpun kepadaku. Dan kemarahanku kepadanya jauh lebih memuncak daripada kepada Utsman. Lalu aku menunggu beberapa malam, ternyata Rasulullah SAW meminangnya. Maka aku menikahkannya dengan beliau. Kemudian Abu Bakr menemuiku dan berkata, "Sepertinya engkau marah kepadaku ketika engkau menawarkan Hafshah kepadaku dan aku tidak memberi jawaban sedikitpun." Aku menjawab, "Ya." Abu Bakr berkata, "Sebenarnya tidak ada yang menghalangiku untuk memberi jawaban kepadamu mengenai apa yang engkau 
tawarkan kepadaku, kecuali aku mengetahui bahwa Rasulullah SAW sering menyebut-nyebutnya, dan tidak mungkin aku akan menyebarkan rahasia Rasulullah SAW. Kalaulah beliau meninggalkannya, tentu aku akan menerima tawaranmu." \{Bukhari - 3704\}

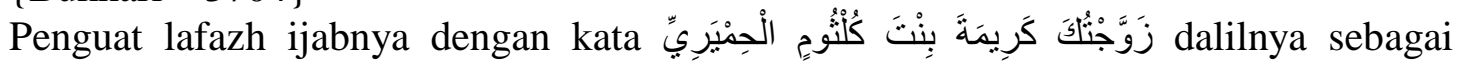
berikut

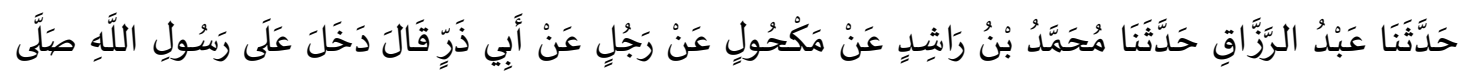

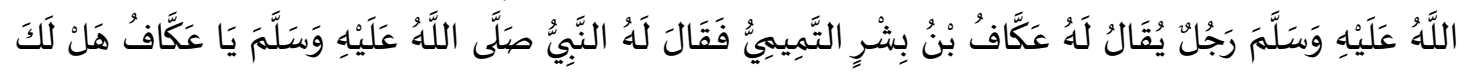

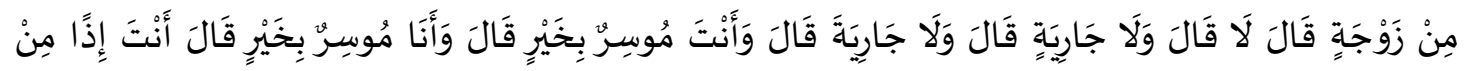

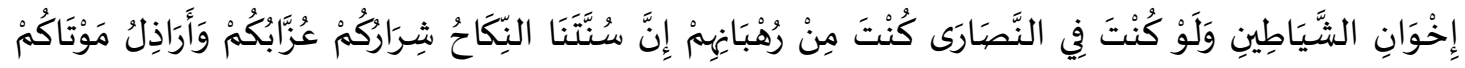

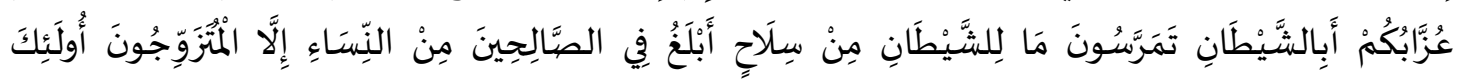

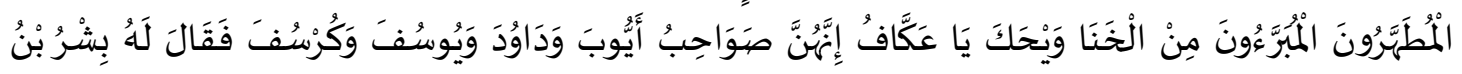

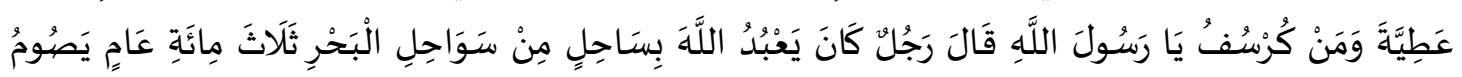

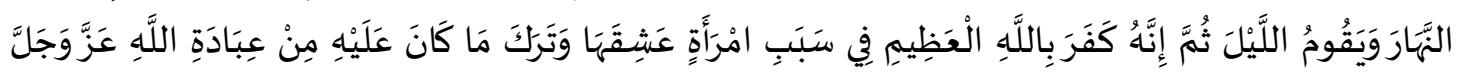

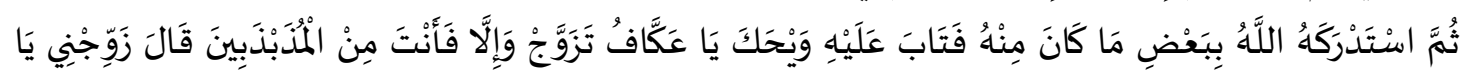

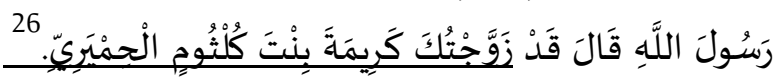

Artinya: Telah menceritakan kepada kami Abdurrazaq telah menceritakan kepada kami Muhammad bin Rasyid dari Makhul dari seseorang dari Abu Dzar dia berkata, "Seorang laki-laki yang bernama Akkaf bin Bisyr at-Taimi datang menemui Rasulullah Shallalahu 'Alaihi Wasallam. Kemudian Nabi Muhammad SAW bertanya kepadanya: "Wahai 'Akkaf, apakah kamu mempunyai seorang isteri?" Dia menjawab, "Tidak." Nabi bertanya lagi; "Tidak juga seorang budak wanita?" Dia kembali menjawab, "Tidak juga budak wanita." Nabi bersabda: "Engkau dalam keadaan lapang?" Ia menjawab, "Ya, saya dalam keadaan lapang." Nabi Muhammad SAW wasallam pun bersabda: "Kalau begitu kamu termasuk saudara-saudara setan, seandainya kamu orang Nasrani pasti kamu termasuk para pendeta mereka. Sesungguhnya sunnah kami adalah menikah, orang yang paling buruk di antara kalian adalah orang yang masih bujang, dan mayit kalian yang paling hina adalah orang yang meninggal dalam keadaan masih bujang. Apakah kalian hendak melawan setan padahal tidak ada senjata setan yang paling ampuh untuk melawan orang-orang shalih selain wanita? Kecuali bagi orang-orang yang sudah beristeri mereka itulah orangorang yang disucikan lagi dihindarkan dari perbuatan keji. Celakalah kamu wahai 'Akkaf! Sesungguhnya para wanita itu adalah pendamping-pendamping Ayyub, Daud, Yusuf dan Kursuf." Bisyr bin 'Athiyah lalu bertanya kepada beliau, "Siapa Kursuf itu wahai Rasulullah?" Beliau menjawab: "Dia adalah seorang lelaki yang beribadah kepada Allah di tepi laut selama tiga ratus tahun; siangnya dia berpuasa dan malamnya dia shalat, namun kemudian ia kafir kepada Allah yang Maha Agung disebabkan seorang wanita yang dia sukai, dan dia tinggalkan kebiasaan ibadahnya kepada Allah Azza Wa Jalla. Kemudian Allah mengembalikan dia menjadi baik sehingga dia bertaubat. celaka kamu wahai 'Akkaf, hendaklah engkau menikah! Apabila tidak berarti kamu termasuk orang yang ragu ragu." Kemudian 'Akkaf berkata, "Nikahkan aku wahai Rasulullah!" Beliau lalu bersabda: "Aku nikahkan kamu dengan Karimah binti Kultsum Al Himyari. \{Ahmad - 20477\}

r. Sedangkan langsung wali nasab masih menyebutkan nama ayah dan putrinya 
s. Kenapa diterima lafazh ijab qabul tidak disebutkan nama ayah dan putrinya dalam perwakilan

t. Hafalannya dilakukan setelah akad nikah, bukan sebelum akad nikah

u. Jadi jelas, bahwa hadis di atas menjelaskan rentetan minimnya mahar, mulai dari sehelai kain, cincin dari besi, dan hafalan al-Qur'an dua surah, bukan wajibnya lafazh ijab qabul akad nikah menyebutkan jumlah mahar, walaupun surah an-Nisa' 4:24 wajib hukum mahar dan dalil sunnah menentukan mahar yaitu surah an-Nisa' 4:4

v. Seandainya Nabi mau menikahi wanita itu siapa yang menjadi wali nasabnya, perlu direnungkan kembali lagi, apabila Nabi sebagai wali perwakilan menikahkannya kepada laki-laki itu

w. Setiap perwakilan tentu wajib ada yang memberikan perwakilan kepada wali hakim

x. Atau wajib ada izin dari pihak wanita tersebut, surah an-Nisa' ayat 24 dan surah alBaqarah ayat 32

y. Kemudian dalam matan hadis terdapat kata ditemukan dalam hadis lain yang berkaitan dengan lafazh ijab qabul

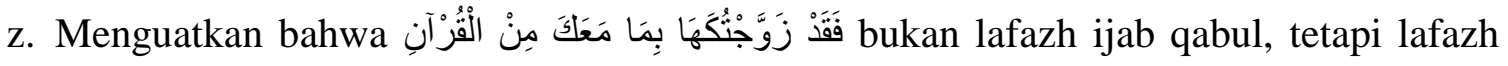
bolehnya melanjutkan akad nikah dengan mahar hafalan al-Qur'an

Hukum yang bisa dipetik dari kisah Nabi Syu'aib tentang mahar di atas adalah:

1. Kesepakatan orangtua wanita dengan calon suami serta orangtuanya syaratnya kuat dan terpercaya dari segi akidah, syariah dan akhlaknya yang mulia, ekonomi semuanya syaratnya arus didasari dengan ilmu al-Qur'an hadis dan sirah nabawi

2. Kemudian putri Nabi Syu'aib mau untuk dinikahkan kepada calon suami atas pertimbangan dua orangtuanya

3. Merupakan isyarat berharga bahwa dua orang yang bersaudari umpamakan adek kakak, tidak boleh dijadikan penghalang siapa duluan menikah, dengan ukuran bagi calon suami mana yang dia sukai, tentu demikian adek abang pria silakan siapa duluan dengan indikator terpenuhi syarat dan rukun nikahnya

4. Dalam ayat di atas jelas lafazh untuk menginginkan menikahkan adalah lafazh fi'il mudhori' (waktui sekarang atau yang akan datang) bukan fi'il madhi (waktu masa yang sudah lewat) 
5. Harus langsung di dengar calon suami dan calon isteri hasrat untuk menikah dengan baik dengan lambang kata إِحْدَى ابْنَتََّّ هَانَتَنِ salah satu dua putriku ini, berarti hadir dua-duanya di majelis peminangan itu

6. Dalam ayat ini yang dipinang adalah masih gadis belum menikah sebelumnya

7. Berarti pelaksanaan peminangan harus langsung dihadapan wali kepada calon isteri, calon suami, kisah ini diperjelas surah al-Baqarah ayat 235 berikut:

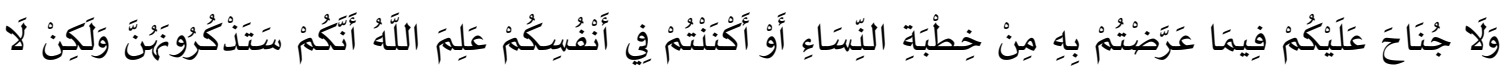

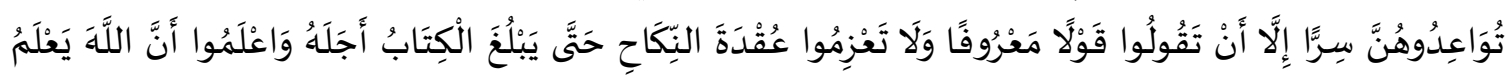

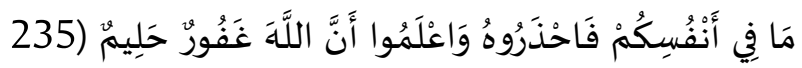

"Dan tidak ada dosa bagi kamu meminang wanita-wanita itu ${ }^{[148]}$ dengan sindiran ${ }^{[149]}$ atau kamu menyembunyikan (keinginan mengawini mereka) dalam hatimu. Allah mengetahui bahwa kamu akan menyebut-nyebut mereka, dalam pada itu janganlah kamu mengadakan janji kawin dengan mereka secara rahasia, kecuali sekedar mengucapkan (kepada mereka) perkataan yang ma'ruf. Dan janganlah kamu ber'azam (bertetap hati) untuk beraqad nikah, sebelum habis 'iddahnya. Dan ketahuilah bahwasanya Allah mengetahui apa yang ada dalam hatimu; maka takutlah kepada-Nya, dan ketahuilah bahwa Allah Maha Pengampun lagi Maha Penyantun. Yang suaminya telah meninggal dan masih dalam 'iddah. Wanita yang boleh dipinang secara sindiran ialah wanita yang dalam 'iddah karena meninggal suaminya, atau karena talak bain, sedang wanita yang dalam 'iddah talak raji'i tidak boleh dipinang walaupun dengan sindiran. .Perkataan sindiran yang baik. ${ }^{27}$

8. Perawan atau janda wajib didahului peminagan sebelum melangsungkan akad nikah jangan didahului dengan pacaran

9. Haramnya pacaran sebelum menikah, dalilnya sebagai berikut:

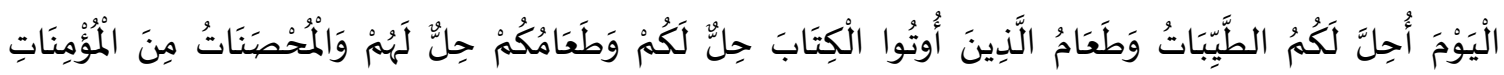

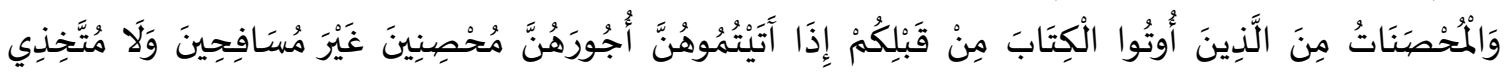

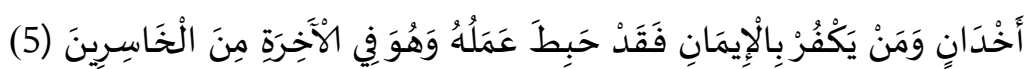

"Pada hari ini dihalalkan bagimu yang baik-baik. Makanan (sembelihan) orang-orang yang diberi Al Kitab itu halal bagimu, dan makanan kamu halal (pula) bagi mereka. (Dan dihalalkan mangawini) wanita yang menjaga kehormatan diantara wanita-wanita yang beriman dan wanita-wanita yang menjaga kehormatan di antara orang-orang yang diberi Al Kitab sebelum kamu, bila kamu telah membayar mas kawin mereka dengan maksud menikahinya, tidak dengan maksud berzina dan tidak (pula) menjadikannya gundikgundik. Barangsiapa yang kafir sesudah beriman (tidak menerima hukum-hukum Islam) maka hapuslah amalannya dan ia di hari kiamat termasuk orang-orang merugi. Ada yang mengatakan wanita-wanita yang merdeka". ${ }^{28}$

Sejarah Mahar dalam Islam

Analisis dan Aplikasinya: Lanjutan ayat surah al-Qasash ayat 27 sebagai berikut: عَلَى أَنْ تَأَجْرَنِي artinya: Atas dasar bahwa kamu bekerja denganku delapan tahun dan 
apabila kamu cukupkan sepuluh tahun. Hukum yang berkaitan dengan ayat ini adalah tentang syarat akad nikah adalah mahar, aplikasinya sebagai berikut:

1. Seorang calon suami harus ada dulu pekerjaan rutinnya yang baik dan ikhlas serta diridai Islam sebelum menikah

2. Kemudian dari hasil kerjanya itu merupakan modal untuk memperoleh mahar yang akan diberikan kepada calon isterinya, serta modal lanjutan setelah menikah, hal ini sesuai dengan ayat berikut:

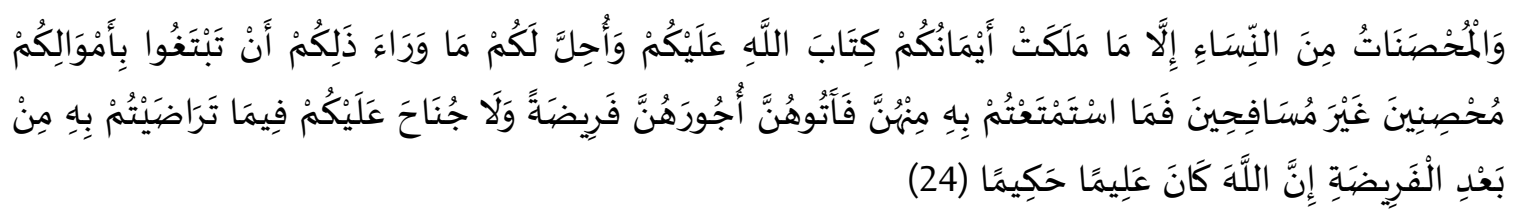
“dan (diharamkan juga kamu mengawini) wanita yang bersuami, kecuali budak-budak yang kamu miliki (Allah telah menetapkan hukum itu) sebagai ketetapan-Nya atas kamu. Dan dihalalkan bagi kamu selain yang demikian (yaitu) mencari isteri-isteri dengan hartamu untuk dikawini bukan untuk berzina. Maka isteri-isteri yang telah kamu nikmati (campuri) di antara mereka, berikanlah kepada mereka maharnya (dengan sempurna), sebagai suatu kewajiban; dan tiadalah mengapa bagi kamu terhadap sesuatu yang kamu telah saling merelakannya, sesudah menentukan mahar itu. Sesungguhnya Allah Maha Mengetahui lagi Maha Bijaksana. Maksudnya: budak-budak yang dimiliki yang suaminya tidak ikut tertawan bersama-samanya. ${ }^{29}$

3. Harus didengar oleh calon suami dan calon isteri atas ajuan dua orangtua calon isteri

4. Manfaatnya agar bertanggungjawab kedua belah pihak atas tawaran, serta jawaban calon suami dapat di dengar calon isteri atas relanya calon suami

5. Besaran mahar dalam ayat ini sekedar menggambarkan syarat akad nikah, bukan harus seperti itu besarannya dan caranya

6. Besaran mahar tentu disesuaikan dengan kemampuan calon suami

7. Mahar pada zahirnnya membuat beban kepada calon suami, tetapi hakikatnya suatu

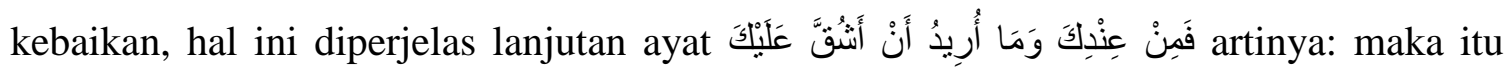
adalah (suatu kebaikan) dari kamu, maka aku tidak hendak memberati kamu

8. Maksud suatu kebaikan adalah, di mana mahar itu merupakan modal kerja untuk hidup kedepan yang lebih baik dibandingkan dengan hidup sesama dua orangtua sebelumnya

9. Makanya mahar apabila disepakati boleh diberikan isteri kepada suaminya apabila diperlukan untuk makanan apalagi untuk modal hidup sekaligus hukum mahar itu sunat dalilnya suroh an-Nisa' ayat 4 sebagai berikut: 


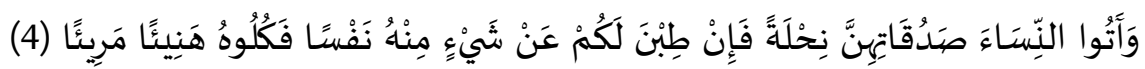
"Berikanlah maskawin (mahar) kepada wanita (yang kamu nikahi) sebagai pemberian dengan penuh kerelaan. Kemudian apabila mereka menyerahkan kepada kamu sebagian dari maskawin itu dengan senang hati, maka makanlah (ambillah) pemberian itu (sebagai makanan) yang sedap lagi baik akibatnya. Pemberian itu ialah maskawin yang besar kecilnya ditetapkan atas persetujuan kedua pihak, karena pemberian itu harus dilakukan dengan ikhlas". 30

10. Kemudian secepatnya mampu hidup mandiri untuk mengabdi kepada dua orangtua, kirabat dan lainya di surah al-Baqarah ayat 215 alinya sebagai berikut:

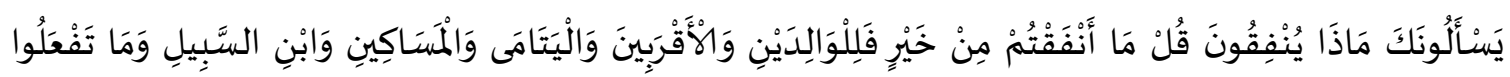

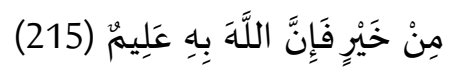
"Mereka bertanya tentang apa yang mereka nafkahkan. Jawablah: "Apa saja harta yang kamu nafkahkan hendaklah diberikan kepada ibu-bapak, kaum kerabat, anak-anak yatim, orang-orang miskin dan orang-orang yang sedang dalam perjalanan." Dan apa saja kebaikan yang kamu buat, maka sesungguhnya Allah Maha Mengetahuinya". ${ }^{31}$

Aplikasi:

a. Apabila suami membawa oleh-oleh maka isteri wajib memberikannya kepada mertua wanita

b. Maka mertua wanita atau ibu suami yang membaginya kepada suaminya dan anak serta menantu

c. Demikian juga hal lain, maka yakinlah isteri mertua kamu akan mencintaimu, serta suami pasti mencintaimu, Karena kamu para isteri telah mencintai orang yang paling dicintai oleh suamimu yaitu kedua orangtuanya. Hal seperti ini mengamalkan surah Ali 'Imran ayat 31

11. Manusia yang terbaik adalah manusia yang terbaik dan terbanyak memberikan manfaat kepada dua orangtuanya dan manusia lainnya

12. Bayangkan saudara berapa lama penentuan mahar sepuluh tahun sebelum pelaksanaan akad nikah, apakah masih perlu penyebutan mahar saat akad nikah, yang dipahami sebahagian ulama kita

13. Potongan ayat selanjutnya adalah: jaminan Allah atas perlakuan pinangan dan penentuan mahar yang disepakatai adalah إِنْ شَاءَ اللَّهُ مِنَ الصَّالِِِينَ artinya: Kamu Insya Allah akan mendapatiku termasuk orang- orang yang baik 
14. Sejarah membuktikan Musa menajdi Nabi, mampu melawan musuh Allah yaitu Fir'aun dan bala tentaranay, banyak Bani Isroil menjadi muslim, selamat dari kejaran Fir'aun, menerima kitab Taurot dan Shuhuf sebelumnya

15. Kata shilihin adalah jama' berarti dua pengantin dan ditambah dengan kirabat mereka berdua seharusnya mampu mensolihkannya setelah menikah, jangan menjadi pengkhianat dan pemisah dua pihak keluarga

16. Istilah lain jadilah kalian berdua jahit menemukan yang berpisah, jangan menjadi perobek seperti gunting

17. Aplikasi doa menjadi manusia yang solih adalah bacaan doa saat tasyahud awal dan akhir, serta mengamlakan hadis Rosul doa anak solih akan barlanjut dunia dan akhirat

Waktu Penyerahan Mahar

1. Ayat di atas menjelaskan bahwa Nabi Syu'aib memberikan upah kepada Musa berupa kambing yang banyak yang diperuntukkan untuk mahar calon isterinya serta modal kerja selanjutnya setelah menikah dalilnya surah al-Qasash ayat 29 sebagai berikut:

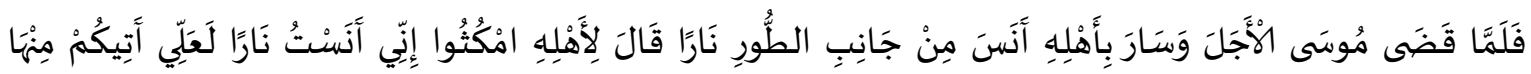

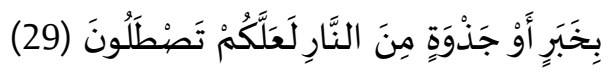
"Maka tatkala Musa telah menyelesaikan waktu yang ditentukan dan dia berangkat dengan keluarganya, dilihatnyalah api di lereng gunung ia berkata kepada keluarganya: "Tunggulah (di sini), sesungguhnya aku melihat api, mudah-mudahan aku dapat membawa suatu berita kepadamu dari (tempat) api itu atau (membawa) sesuluh api, agar kamu dapat menghangatkan badan.". Setelah Musa a.s. menyelesaikan perjanjian dengan Syu'aib a.s. ia berangkat dengan keluarganya dengan sejumlah kambing yang diberi mertuanya, maka pada suatu malam yang sangat gelap dan dingin Musa a.s. tiba di suatu tempat tetapi setiap beliau menghidupkan api, api itu tidak mau menyala. Hal itu sangat mengherankan Musa maka ia berkata kepada istrinya sebagai tersebut dalam ayat 29 ". ${ }^{32}$

2. Timbul permasalahan kapan diberikan yang pasti oleh Musa kepada Isterinya, tidak ada lafazh yang menjelaskannya dalam ayat ini jawabnya dijelaskan surah al-Baqarah ayat 236 berikut:

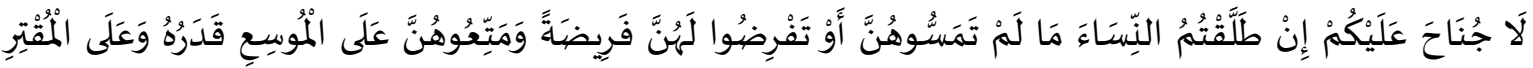

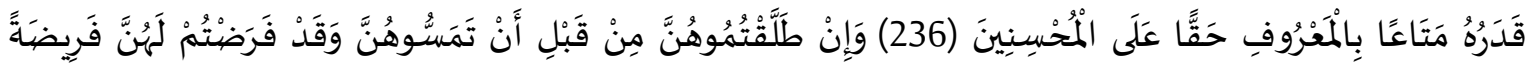

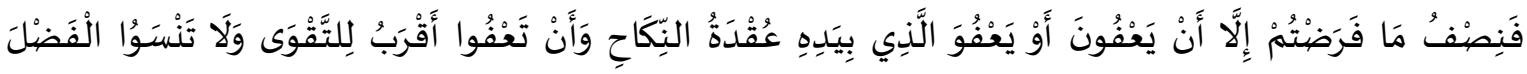

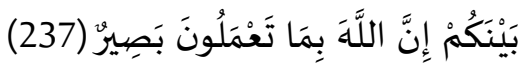
"Tidak ada kewajiban membayar (mahar) atas kamu, apabila kamu menceraikan isteriisteri kamu sebelum kamu bercampur dengan mereka dan sebelum kamu menentukan maharnya. Dan hendaklah kamu berikan suatu mut'ah (pemberian) kepada mereka. Orang yang mampu menurut kemampuannya dan orang yang miskin menurut kemampuannya (pula), yaitu pemberian menurut yang patut. Yang demikian itu merupakan ketentuan bagi 
orang-orang yang berbuat kebaapabilan." "Apabila kamu menceraikan isteri-isterimu sebelum kamu bercampur dengan mereka, padahal sesungguhnya kamu sudah menentukan maharnya, maka bayarlah seperdua dari mahar yang telah kamu tentukan itu, kecuali apabila isteri-isterimu itu mema'afkan atau dima'afkan oleh orang yang memegang ikatan nikah, dan pema'afan kamu itu lebih dekat kepada takwa. Dan janganlah kamu melupakan keutamaan di antara kamu. Sesungguhnya Allah Maha Melihat segala apa yang kamu kerjakan. Ialah suami atau wali. Kalau wali mema'afkan, maka suami dibebaskan dari membayar mahar yang seperdua, sedang kalau suami yang mema'afkan, maka dia membayar seluruh mahar". 33

3. Jadi pemberian mahar oleh suami setelah senggama awal, agar isteri tidak ada kesempatan membodohi calon suaminya

4. Contoh rilnya dalam penomenanya isteri berkata sebelum menikah aku masih perawan pada hal bukan lagi, maka awal malam pertama isteri bilang sama suami, aku sedang haid, antarkan aku pulang sementara ke rumah orangtuaku

5. Setelah habis masa haidku aku beri tahu agar abang menjemput saya

6. Ternayata dia lari atau kabur menikah dengan laki-laki lain

7. Karena sudah dapat akta nikah sebagai tanda janda terhormat, dan sudah mendapat mahar sekian juta

8. Solusinya amalkan ayat-ayat waktu pemberian disarankan kepada calon suami saat awal malam pertama katakana sejujurnya kepada sama isteri, apabila kamu nanti ternyata masih perawan maka semua mahar ini milikmu, namun apabila tidak maka anda tidak ada hakmu sedikitpun

9. Yakinlah anda apabila masih perawan maka dia mau dites, apabila tidak tentu dia tidak mau senggama dengan kamu

10. Apabila bertahan mau dites untuk membela diri tas dustanya disarakna kepada para suami lakukan cara mentesnya, ambil sarung tangan terbuat dari karet tipis, kemudian masukkan jari kelingkingmu, apabila teriak benaran dan kesakitan yang amat, maka masukkan lagi induk jarimu tentu dia tambah sakit, maka insya Allah masih perawan, apabila tidak menjerit tentu sebaliknya, ceraikan sajalah, dalam mengamalkan \{Qs. anNur 24/3 \} Karena Kecantikan :

1. Balig artinya seorang wanita balig adalah keluar haid, umurnya boleh saja berbeda dengan wanita lain dalilnya surah al-Baqarah ayat 222-223 sebagai berikut:

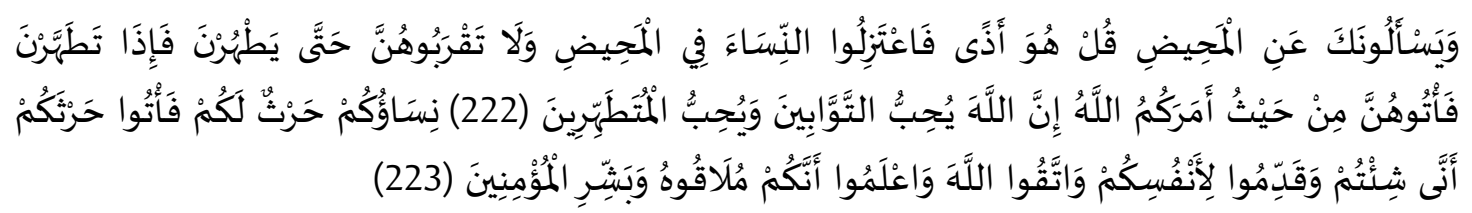


"Mereka bertanya kepadamu tentang haidh. Katakanlah: "Haidh itu adalah suatu kotoran." Oleh sebab itu hendaklah kamu menjauhkan diri dari wanita di waktu haidh; dan janganlah kamu mendekati mereka, sebelum mereka suci. Apabila mereka telah suci, maka campurilah mereka itu di tempat yang diperintahkan Allah kepadamu. Sesungguhnya Allah menyukai orang-orang yang bertaubat dan menyukai orangorang yang mensucikan diri. Maksudnya menyetubuhi wanita di waktu haidh. Ialah sesudah mandi. Adapula yang menafsirkan sesudah berhenti darah keluar".

"Isteri-isterimu adalah (seperti) tanah tempat kamu bercocok tanam, maka datangilah tanah tempat bercocok-tanammu itu bagaimana saja kamu kehendaki. Dan kerjakanlah (amal yang baik) untuk dirimu, dan bertakwalah kepada Allah dan ketahuilah bahwa kamu kelak akan menemui-Nya. Dan berilah kabar gembira orangorang yang beriman". 34

Khusus di Indonesia ada diatur minimal umur calon suami yaitu 18 tahun dan calon

Isteri 16 tahun. Penetapan ini untuk menjaga agar jangan cepat terjadi perceraian, ada pengguguran dan keguguran, bahkan sering terjadi perpacaran setelah menikah. Tetapi akibat pembatasan usia itu, timbul persoalan seringnya anak umur sebelum batas tersebut melakukan perzinaan. Kemudian di Indonesia usia tersebut masih usia sekolah tingkat pertama dan tingkat atas. Anak masih sekolah dilarang sekolah wajib berhenti. Maka menjadi problema umur anak wanita haid sudah boleh menikah, tersangkut masa sekolah.

Apabila calon suami sudah pernah mimpi basah dalilnya:

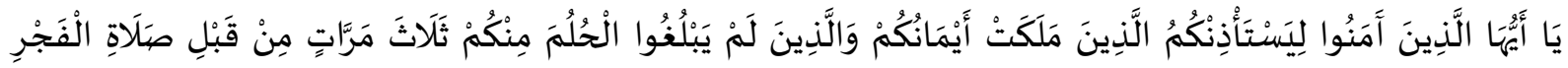

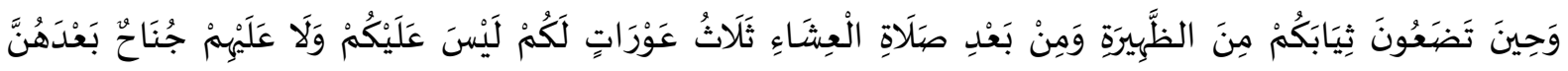

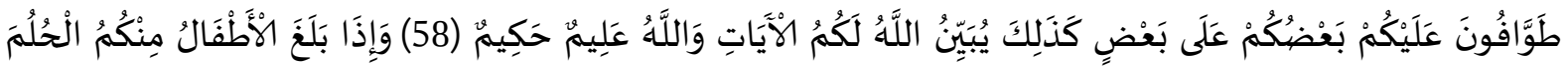

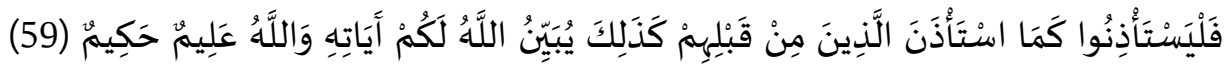
"Hai orang-orang yang beriman, hendaklah budak-budak (lelaki dan wanita) yang kamu miliki, dan orang-orang yang belum balig di antara kamu, meminta izin kepada kamu tiga kali (dalam satu hari) yaitu: sebelum solat subuh, ketika kamu menanggalkan pakaian (luar)mu di tengah hari dan sesudah solat Isya'. (Itulah) tiga 'aurat bagi kamu. Tidak ada dosa atasmu dan tidak (pula) atas mereka selain dari (tiga waktu) itu. Mereka melayani kamu, sebahagian kamu (ada keperluan) kepada sebahagian (yang lain). Demikianlah Allah menjelaskan ayat-ayat bagi kamu. Dan Allah Maha Mengetahui lagi Maha Bijaksana.. Maksudnya: tiga macam waktu yang biasanya di waktu-waktu itu badan banyak terbuka. Oleh sebab itu Allah melarang budak-budak dan anak-anak dibawah umur untuk masuk ke kamar tidur orang dewasa tanpa idzin pada waktu-waktu tersebut. Maksudnya: tidak berdosa kalau mereka tidak dicegah masuk tanpa izin, dan tidak pula mereka berdosa kalau masuk tanpa meminta izin".

"Dan apabila anak-anakmu telah sampai umur balig, maka hendaklah mereka meminta izin, seperti orang-orang yang sebelum mereka meminta izin. Demikianlah Allah menjelaskan ayat-ayat-Nya. Dan Allah Maha Mengetahui lagi Maha Bijaksana. Maksudnya: anak-anak 
dari orang-orang yang merdeka yang bukan maharam, yang telah balig haruslah meminta izin lebih dahulu kalau hendak masuk menurut cara orang-orang yang tersebut dalam ayat 27 dan 28 surat ini meminta izin".

Penjelasan surah an-Nur ayat 27-29 dan 61

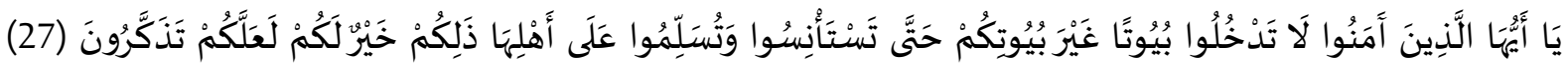

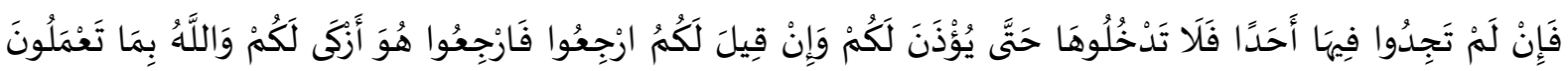

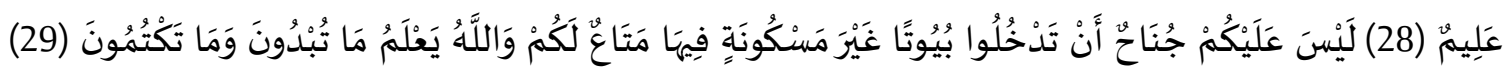

"Hai orang-orang yang beriman, janganlah kamu memasuki rumah yang bukan rumahmu sebelum meminta izin dan memberi salam kepada penghuninya. Yang demikian itu lebih baik bagimu, agar kamu (selalu) ingat". "Apabila kamu tidak menemui seorangpun didalamnya, maka janganlah kamu masuk sebelum kamu mendapat izin. Dan apabila dikatakan kepadamu: "Kembali (saja)lah, maka hendaklah kamu kembali. Itu bersih bagimu dan Allah Maha Mengetahui apa yang kamu kerjakan". "Tidak ada dosa atasmu memasuki rumah yang tidak disediakan untuk didiami, yang di dalamnya ada keperluanmu, dan Allah mengetahui apa yang kamu nyatakan dan apa yang kamu sembunyikan".

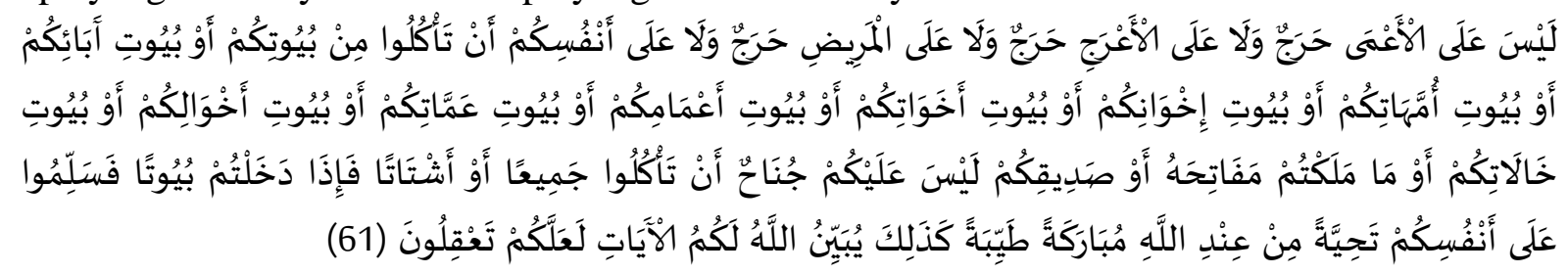
“Tidak ada halangan bagi orang buta, tidak (pula) bagi orang pincang, tidak (pula) bagi orang sakit, dan tidak (pula) bagi dirimu sendiri, makan (bersama-sama mereka) dirumah kamu sendiri atau dirumah bapak-bapakmu, dirumah ibu-ibumu, dirumah saudara- saudaramu yang laki-laki, di rumah saudaramu yang perempuan, dirumah saudara bapakmu yang laki-laki, dirumah saudara bapakmu yang perempuan, dirumah saudara ibumu yang laki-laki, dirumah saudara ibumu yang perempuan, dirumah yang kamu miliki kuncinya atau dirumah kawankawanmu. Tidak ada halangan bagi kamu makan bersama-sama mereka atau sendirian. Maka apabila kamu memasuki (suatu rumah dari) rumah- rumah (ini) hendaklah kamu memberi salam kepada (penghuninya yang berarti memberi salam) kepada dirimu sendiri, salam yang ditetapkan dari sisi Allah, yang diberi berkat lagi baik. Demikianlah Allah menjelaskan ayatayatnya(Nya) bagimu, agar kamu memahaminya. Maksudnya: rumah yang diserahkan kepadamu mengurusnya". 35

Analisis:

1. Amalkan waktu senggama yang tiga waktu tersebut dengan ikhlas dan penuh tanggungjawab pada waktu normal

2. Namun apabila terlalul mendesak, maka boleh saja diamalkan seperti seorang suami atau isteri baru pulang dari musafir, atau barusan habis haid atau nifas, juga malam pertama menikah, atau salah satu suami atau isteri mau berangkat musafir tentu butuh wati sebelumnya agar terhindar sedikit di tujuan musafir maslah wati atau godaan lain

3. Banyakkan pengantar wati agar sama-sama ejakulasi sampai isteri minta dimasukkan kepala penis suami dan insya Allah akan berhasil pembuahan 
4. Sekedar usaha, di mana rahim isteri dua sebelah kanan unuk anak pria, rahim sebelh kiri untuk wanita, maka aplikasinya mau ejakulasi, suami usahakan menyilang ke kanan isteri agar tumpah maninya kea rah rahim sebelah kanan, apabila mau anak wanita menyilang ke sebelah kiri isteri

5. Lakukan demikian sampai hamil betul isteri

6. Makanan tambahan untuk keharmonisan wati maka lakukan berikut:

a. Beli jahe, kunyit, lempuyang, masing-masing $1 / 4 \mathrm{~kg}$, kupas, tumbuk semuanya, rebus 7 gelas air, sampai sisa 3 gelas airnya, saring, masukkan ke gelas, campur dengan madu secukupnya, putih pinang muda masih encerlagi, kuning telur ayam kampung, minum 3 kali sehari semalam

b. Amalkan seminggu sebelum menikah, lakukan apabila mau dibutuhkan

c. Rasakan manfaatnya agar keharmonisan terus terasa baik dan berguna

\section{Karena Agama:}

Islam dalilnya surah al-Baqarah ayat 221 sebagai berikut:

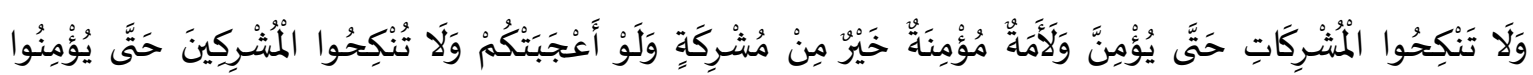

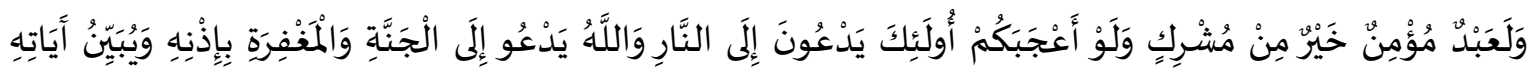

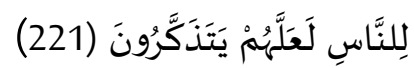

"Dan janganlah kamu menikahi wanita-wanita musyrik, sebelum mereka beriman. Sesungguhnya wanita budak yang mukmin lebih baik dari wanita musyrik, walaupun dia menarik hatimu. Dan janganlah kamu menikahkan orang-orang musyrik (dengan wanitawanita mukmin) sebelum mereka beriman. Sesungguhnya budak yang mukmin lebih baik dari orang musyrik, walaupun dia menarik hatimu. Mereka mengajak ke neraka, sedang Allah mengajak ke surga dan ampunan dengan izin-Nya. Dan Allah menerangkan ayatayat-Nya (perintah-perintah-Nya) kepada manusia supaya mereka mengambil pelajaran". ${ }^{36}$ Analisis:

a. Apabila seorang musyrik masuk Islam maka harta yang dia peroleh menjadi halal diperguanakan setelah masuk Islam seperti para sahabat Rosul

b. Namun jangan diulangi kembali cara memperolehnya seperti saat masih kapir contoh hasil main judi, prustitusi, hasil khomar, korupsi dan sebagainya yang diharamkan Islam

7. Berwuduk dan shalat mutlaq sebelumnya, jangan telanjang bulat, baca doa senggama, doa saat ejakulasi dan doa selesai senggama, doanya berikut:

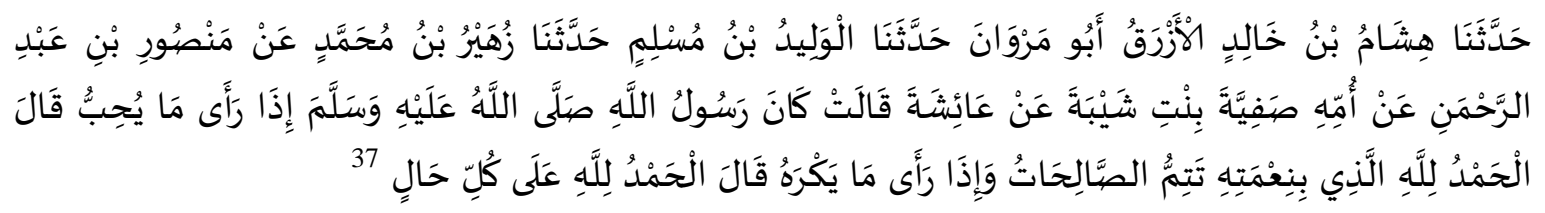


Artinya: Telah menceritaan: kepada kami Hisyam bin Khalid Al Azraq Abu Marwan telah menceritakan kepada kami Al Walid bin Muslim telah menceritakan kepada kami Zuhair bin Muhammad dari Manshur bin Abdurrahman dari ibunya yaitu Shafiyah binti Syaibah dari 'Aisyah dia berkata; "Apabila Rasulullah shallallahu 'alaihi wasallam melihat sesuatu yang ia senangi, beliau mengucapkan: "Segala puji bagi Allah yang dengan nikmat-Nya semua kebaikan menjadi sempurna." dan apabila melihat sesuatu yang dibenci, beliau mengucapkan: "Segala puji bagi Allah atas setiap keadaan." \{ Ibnu Majah - 3793\}

8. Masuk rumah sendiri, dan rumah yang kosong, lokal kuliah, sekolah, atau rumah di mana kita bebas makan bersama atau sendirian, maka ketok pintu rumah tersebut apabila sedang terkunci, dibuka maka baca ucapan salamnya السَّلامُ عَلَيْنَ artinya keselamatan atas kita (kita termasuk yang seisi rumah dan yang datang sebagai tamu)

9. Tidak perlu lagi menjawab salamnya, namun apabila rumah orang lain diluar rumah yang

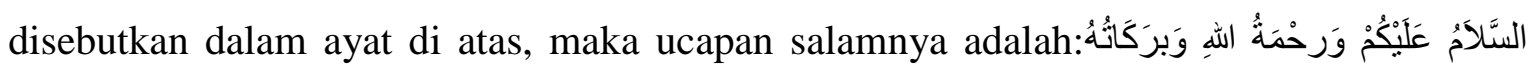
artinya keselamatan, rahmat dan keberkatan Allah kepada kamu. Maka jawabannya wajib hukumnya dalillnya sebagai berikut:

$$
\text { وَعَلَيْكُمُ السَّلالَمُ وَرحْمَاُُ اللَهِ وَبرَكَاتُهُ }
$$

10. Jangan lupa doa masuk rumah siapapun dengan berbisik, dalilnya sebagai berikut:

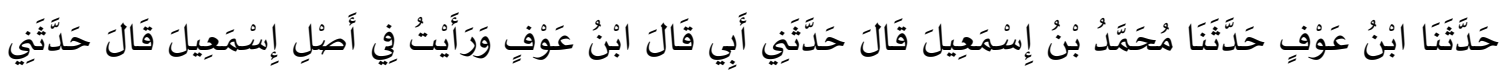

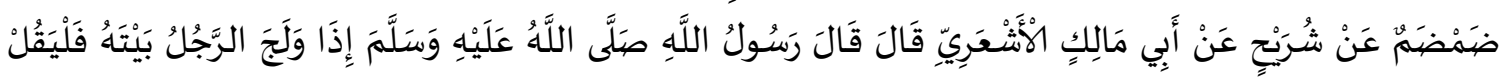

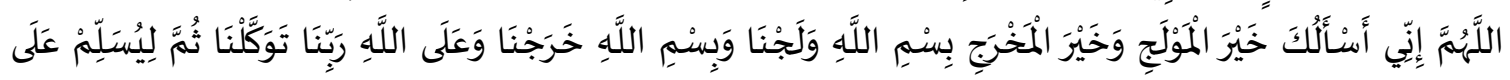

$$
\begin{aligned}
& \text { أَهْلِهِ } 38
\end{aligned}
$$

Artinya: Telah menceritakan kepada kami Ibnu Auf berkata, telah menceritakan kepada kami Muhammad bin Isma'il ia berkata; telah menceritakan kepadaku Bapakku. Ibnu Auf berkata; Aku pernah melihat dalam buku Isma'il ia berkata; telah menceritakan kepadaku Dhamdham dari Syuraih dari Abu Malik Al Asy'ari ia berkata, "Rasulullah SAW bersabda: "Apabila seorang laki-laki masuk ke dalam rumahnya hendaklah ia membaca: 'allahumma innii as`aluka khairal maulaj wa khairal makhraj bimillah walajnaa wa bismillahi kharajnaa wa 'alaallahi rabbinaa tawakkalnaa (Ya Allah, sesungguhnya aku minta kepada-Mu kebaikan tempat masuk dan tempat keluar. Dengan menyebut nama Allah, kami masuk (rumah) dan dengan menyebut nama Allah kami keluar). ' Setelah itu hendaklah mengucapkan salam kepada keluarganya." \{Abu Daud 4432\}

11. Masuklah dengan menutup aurat, sampaikan tujuan, jangan berlama-lama apalagi ada yang kurang sehat

Jangan wanita yang digauli secara tidak syah. Malik mengatakan tentang laki-laki yang berzina dengan seorang wanita, kemudian diberlakukan had zina. Maka apabila janda, anak wanita tersebut boleh dinikahi laki-laki yang sudah dilakukan had zinanya. Kemudian anak laki-laki pezina tadi boleh menikahi wanita yang dizina oleh bapaknya. Alasan karena persetubuhan tersebut dengan cara haram. Yang diharamkan isteri ayah yang sudah 
disetubuhi ayah kandung. Demikian maksud surah A-Nisa' ayat 22. Demikian juga seorang laki-laki menikahi wanita masih masa iddah dan menggaulinya. Maka wanita tersebut wajib diceraikan. Kemudian wanita itu haram bagi anak laki-laki kandung tersebut. Namun tidak diberlakukan had zina, karena pernikahannya syah. Apabila hasil persetubuhan mereka ada anak wanita atau laki-laki maka dinasabkan kepda laki-laki tersebut. Juga wanita tersebut haram bagi ayah laki-laki itu. Juga ayah laki-laki itu haram menikahi anak wanita dari wanita yang dinikahi dan sempat digaulinya atau belum digaulinya

\section{Penutup}

1. Syarat nikah wajib dipenuhi sebelum melangsungkan ijab qabul akad nikah

2. Hukum mahar ada yag fardu dan yang sunnah

3. Mahar diberikan suami kepada Isteri sesudah wati pertama, apabila sama pengakuan sebelum akad nikah bahawa dia perwaan

4. Apabila tidak perwanan maka wajib diceraikan, karena haram menikah satu di antaranya pernah berzina dengan rela

5. Mahar disepakati sebelum dan ayau sesudah akad nikah

6. Mahar wajib dibayar suami setengahnya apabila diceraikan sebelum wati pertama, nmaun boleh dimaafkan oleh mantan isteri atau walinya, apabila sebelum akad nikah mahar sudah ditentukan bersama dan dan tidak ada iddah, apabila ada penyesalan sama mantan suami ingin menikahinya mulai dari awal peminangan, mahar, ijab qaul

7. Apabila mahar belum ditentukan, nmaun suami mentolaka isteri sebelum diwatinya, maka suami meberikan pemberian kepada isteri sesuai enagn kemampuan mantan suami, dan tidak ada iddah, apabila ada penyesalan sama mantan suami ingin menikahinya mulai dari awal peminangan, mahar, ijab qabul

8. Syarat isteri atau suami Islam, balig, apabila belum tunda wati sesudah balig

9. Apabila masih perwan maunya wanita adalah diamnya, apabila janda harus mengatakan iya atau mau dan istilah lain

10. Izin wali calon isteri wajib diketahui dengan baik jangan direkayasa dan cara penipuan lainnya baik perwaan atau janda

11. Calon suami atau isteri sebaiknya berilmu, berharata, baik keturunan, dan memiliki keagamaan tahu membaca al-Qur'an dan hadis. Mengethui aratinya, fardu 'ain dan kifayah, peraktek ibadah, tahu mana yang haram dan halal, bukan hanya agama Islam KTP saja 
12. Apabila muallaf wajib dulun mendalami ajaran Islam dangan baik

13. Apabila pezian wajib menunggu pernikahan satu tahun dari awal perzinaan, maka wajib tahu kapan awal berzina

14. Pezina sama pezina yang boleh dinikahkan setelah satu tahun ditunggu

15. Apabila ada anak hasil zina wanita, maka menjadi anak Ibu bukan anak ayah, wali nikah nanti saat menikah anak tersebut wali nikah

16. Calon suami atau isteri jangan pezina, LGBT, peminum khomar, perokok, pencuri, pembunuh, penipu

17. Jangan mengumpul atau poligami antara dua bersaudari, dengan putri saudra kandung atau seayah atau seibu, atau dengan bunde isteri baik sekandung atau seibu atau seayah saja, etek dari Ibu baik sekandung atau seibu atau seayah

18. Jangan wanita yang sudah diakad nikahkan kepada anak kandung walaupun belum diwati anak kandung

19. Jangan wanita di mana Ibu kandungnya sudah diwati, apabila belum diwati boleh boleh dinikahi

20. Jangan isteri orang lain baik muslim atau nonmuslim yang masih syah

21. Jangan wanita dalam masih pinangan laki-laki lain, demikian juga wanita masih iddah baik iddah wafat, crai atau wanita yang dili'an oleh suaminya.

\section{DAFTAR PUSTAKA}

Abu Daud, Sunan Abu Daud, Indonesia: An-Nasyir Al-Maktabah Dahlan 275 H.

Ahmad bin Hanbal, Musnad Ahmad, Beirut : Dar al-Katib, al-Ilmiyah, 275 H.

Al-Bukhari, Sahih al-Bukhari, Beirut: Dar al-Fikr,t.t.

An-Nasai, Sunan An-Nasai, Semarang: Maktabah wa Matba'ah, 279 H.

At-Tirmizi, Sunan at-Tirmizi, Semarang: Maktabah wa Matba'ah, $279 \mathrm{H}$

Departemen Agama RI, Al-Quran dan Terjemahannya, Jakarta, Kalim, 2010.

Gunawan, Hendra,. Karakteristik Hukum Islam, Jurnal Al-Maqasid; Jurnal Ilmu Kesyariahan dan Keperdataan Fakultas Syariah dan Ilmu Hukum IAIN Padangsidimpuan, Vol. 4 No. 2. Edisi Juli-Desember 2018.

Ibn Majah, Sunan Ibn Majah, Beirut : Dar al-Katib, al-Ilmiyah, 275 H.

Malik, al-Muwaththo', Beirut: Dar al-Fikr,t.t.

Muslim, Sahih Muslim, Bandung: Dahlan, t.t.

End Note : 
${ }^{1}$ Al-Bukhari, Sahih al-Bukhari , (Beirut: Dar al-Fikr,t.t). hlm.162.

${ }^{2}$ Malik, al-Muwaththo', (Beirut: Dar al-Fikr,t.t). hlm.766.

${ }^{3}$ Al-Bukhari, Op.Cit. hlm.55.

${ }^{4}$ Malik, Op.Cit. hlm.767.

${ }^{5}$ Ibid hlm.20

${ }^{6}$ Ibid hlm. 769.

${ }^{7}$ Ibid hlm. 770 .

${ }^{8}$ Ibid hlm. 771 .

${ }^{9}$ Ibid hlm. 772.

${ }^{10}$ Ibid hlm. 773.

${ }^{11}$ Departemen Agama RI, Al-Quran dan Terjemahannya, (Jakarta, Kalim, 2010) . hlm.102.

${ }^{12}$ Ibid, hlm.64.

${ }^{13}$ Ibid, hlm. 54.

${ }^{14}$ Ibid, hlm. 55.

${ }^{15}$ Al-Bukhari, hlm.127.

${ }^{16}$ An-Nasai, Sunan An-Nasai, (Semarang: Maktabah wa Matba'ah, 279 H), hlm. 382.

${ }^{17}$ Malik,. hlm. 760.

${ }^{18}$ An-Nasai, hlm.166.

${ }^{19}$ Malik,. hlm.10. Penguat Muslim, Sahih Muslim, (Bandung: Dahlan, t.t) . hlm.135

${ }^{20}$ Malik, Ibid, hlm. 762.

${ }^{21}$ Departemen Agama RI, Op.cit, hlm. 30.

${ }^{22}$ Malik,. hlm.763.

${ }^{23}$ Al-Bukhari,. hlm.23.

${ }^{24}$ Departemen Agama RI, hlm. 305.

${ }^{25}$ Al-Bukhari, hlm.213.

${ }^{26}$ Ahmad bin Hanbal, Musnad Ahmad, (Beirut : Dar al-Katib, al-Ilmiyah, 275 H ). hlm. 491.

${ }^{27}$ Departemen Agama RI, hlm. 35.

${ }^{28}$ Ibid, hlm. 45.

${ }^{29}$. Ibid, hlm.37.

${ }^{30}$ Ibid, hlm. 39.

${ }^{31}$ Ibid. hlm. 39.

${ }^{32}$ Ibid. hlm. 276.

${ }^{33}$ Ibid. hlm. 42.

${ }^{34}$ Ibid. hlm. 41.

${ }^{35}$ Ibid. hlm. hlm.313 dan 320.

${ }^{36}$ Departemen Agama RI, hlm. 37.

37 Ibn Majah, Sunan Ibn Majah, (Beirut : Dar al-Katib, al-Ilmiyah, 275 H), hlm. 394. Penguat AtTirmizi, Sunan at-Tirmizi, (Semarang: Maktabah wa Matba’ah, 279 H), hlm.301.

${ }^{38}$ Abu Daud, Sunan Abu Daud, (Indonesia: An-Nasyir Al-Maktabah Dahlan 275 H). hlm.456. 